\title{
The Inter-temporal relationship between Risk, Capital and Efficiency: The case of Islamic and conventional banks
}

\author{
Momna Saeed $^{1 *} \cdot$ Marwan Izzeldin $^{1} \cdot$ M.Kabir Hassan ${ }^{2} \cdot$ Vasileios Pappas $^{3}$ \\ ${ }^{1}$ Lancaster University Management School, Lancaster University, UK \\ ${ }^{2}$ University of New Orleans, US \\ ${ }^{3}$ Kent Business School, University of Kent, UK
}

February 2020

\begin{abstract}
The paper investigates the relationship between risk, capital and efficiency for Islamic and conventional banks using a dataset spanning 14 countries over the 2000-2012 period. We use the z-score as a proxy for insolvency risk, cost efficiency is estimated via a stochastic frontier approach and capitalisation is reflected on the equity to assets ratio. An array of bank-specific, macroeconomic and market structure variables are used in a system of three equations, estimated using the seemingly unrelated regression (SUR) technique. We find that the capitalisation response to increases in insolvency risk is more pronounced for Islamic banks but has an approximately five-times smaller effect on risk mitigation compared to conventional banks. Higher cost efficiency is related to lower risk for conventional banks, but the opposite is true for Islamic banks. The link between cost efficiency and capitalisation attests to a substitutional effect for the case of conventional banks, but a complementary effect for Islamic banks. Our findings give new insights on the use of efficiency to gauge capital requirements for financial institutions and are particularly relevant for regulators and policy makers in countries where both bank types operate.
\end{abstract}

Keywords: Islamic banks, Conventional banks, Capital Ratio, Z-score, Seemingly Unrelated Regression

JEL Classification codes: C33; G21; G28; N25; I5

\footnotetext{
* Corresponding author (momnasaeed@gmail.com). The authors are grateful to participants in the 7th Islamic Economic System Conference 2017 (iECONS2017) (Muscat, Oman) and the 4th International Conference on Applied Theory, Macro and Empirical Finance (Thessaloniki, Greece). The authors acknowledge academic support from the Gulf One Lab for Computational and Economic Research (GOLCER).
} 


\section{Highlights}

We examine the risk, capitalisation and efficiency relationship for IBs/CBs.

IBs show a stronger capitalisation response to increases in insolvency risk.

The risk mitigation effect of capitalisation is muted for Islamic banks.

Changes in efficiency have different impact on the IB/CB risk profiles.

Efficiency complements capitalisation in mitigating risk only in IBs. 


\section{Introduction}

During the last two decades the global banking industry has experienced continual transformations due to various environmental trends including new technologies, deregulation, the globalization of the economy and economic integration. These forces have led to increased financial integration and competition in the financial services industry; this increased concentration in the banking sector coupled with the problems of the recent financial crises has intensified public policy debates about banking regulatory environment and whether existing rules make financial sectors more efficient and stable. The importance of efficiency in banking in general has gained momentum, the result of which has pushed banks to operate closer to the "best practice" banks, which operate in close proximity to the efficient production frontier. Thus, when all banks operate in parallel with each other to achieve higher efficiency levels, competition and market concentration increases which could lead - at least in the short term to greater risk-taking behaviour (Hellman et al., 2000; Altunbas et al., 2007; Fiordelisi et al., 2011a). These banks are deemed riskier because increased competition reduces the market power of banks, which leads to a decrease in their charter values. Furthermore, a decline in bank charter value combined with banks' limited liability and a rather flat-rate deposit insurance encourages banks to take more risks (Matutates and Vives, 2000; Salas and Saurina, 2003; Goddard and Wilson, 2009; Fiordelisi et al., 2011b). Financial regulators have tried to offset risky behaviour by emphasizing upon capital adequacy in the prudential regulatory process as identified in the Basel III proposal. ${ }^{1}$ Capital adequacy requirement affects bank efficiency, which has proven to be one of the most direct contributors to financial stability via its effects on bank failures, future problem loans, and risk-taking (Berger and DeYoung, 1997; Podpiera and Weill, 2008; Podpiera and Pruteanu-Podpiera, 2008; Fiordelisi et al., 2011b). However, this prudential regulation could also have a downside, which raises a concern with regards to its implementation (Pessarossi et al., 2015). Higher capital ratios might impose trade-offs in terms of liquidity creation (Berger and Bouwman, 2009), lending, and output growth (Angelini et al., 2011; BCBS, 2009).

The existing theoretical literature on the determinants of bank risk-taking and efficiency, and more specifically, studies examining the relationship between a bank's capital and risk positions often yield differing expectations. One reason as cited by Altunbas et al. (2007) is that most of the hypotheses are non-exclusive. For instance, agency cost and information asymmetry problems may have a significant impact on trade-offs between risk and bank capital (Jensen, 1986; Berger, 1995) and this explains why some institutions may react to the increased requirements of capital by taking on more risk, while others may reduce leverage. Determining which effect dominates is an empirical question..

The relationship between bank risk, capital and efficiency is not a straightforward one, therefore the three need to be examined together. ${ }^{2}$ (Altunbas et al., 2007) and (Fiordelisi et al., 2011) examine this triple relationship in the European banking sector and find a positive relation between capitalisation and efficiency. By contrast, (Berger and Bonaccorsi di Patti, 2006) only investigate capital and efficiency for US banks find evidence of an inverse relationship. ${ }^{3}$ These studies report contradictory findings:

\footnotetext{
${ }^{1}$ For example, the Basel Committee focus on reforms that intend to raise the quality and quantity of the regulatory capital base and enhance the risk coverage of the capital adequacy framework (Basel Committee, 2011).

${ }^{2}$ Another reason necessitating the simultaneous examination of these variables is that most of the hypothesis are non-exclusive (Altunbas et al., 2007). For instance, agency cost and information asymmetry problems may have a significant impact on trade-offs between risk and bank capital (Berger, 1995; Jensen, 1986) and this explains why some institutions may react to the increased requirements of capital by taking on more risk, while others may reduce leverage.

${ }^{3}$ We are aware that (Kwan and Eisenbeis, 1997) examine capital, risk and efficiency documenting an inverse relationship between capital and efficiency. We are mindful, however of (Altunbas et al., 2007) note on the (Kwan and Eisenbeis, 1997) data limitations. Other reasons for the inconsistency between EU and US studies may include the greater shareholder pressure
} 
Berger and Bonaccorsi di Patti (2006) find that lower capital ratios are associated with higher efficiency, whereas Fiordelisi et al. (2011b) find the opposite.

Given that the aforementioned literature provides contradictory predictions and the evidence on the relationship between capital, risk and efficiency remains non-inclusive, we resort to empirical analysis. In this paper, we explore the role of capitalization on risk-taking behaviour of two different types of banks: Islamic and conventional. The emergence of Islamic banking, a banking system consistent with Shariah principles ${ }^{4}$, is an important development in the financial world. While the purpose of IBs is akin to that of CBs, standard loan and deposit products are fundamentally different, because of the prohibition of interest ( $r i b a)$ in Islam. IBs are not allowed to offer a fixed rate and are expected to conduct operations on the basis of profit-sharing arrangements or other modes of financing permissible under Islamic law. Despite growing pains and a loss of confidence in global financial systems, Islamic finance has continued to show rapid growth. The industry's assets reached \$2 trillion at year-end 2016 (S\&P Global Rating, 2017 ).Between 2006 and 2011, the volume of Shariah-compliant assets doubled to USD 900 billion (Oakley, 2010). Although Shariah-compliant financial assets constitute a small portion of total global banking assets (1.5\%), its rapid growth has been noted by academics, policy makers and practitioners (e.g., Sundarajan and Errico, 2002; Cihak and Hesse, 2010; Beck et al., 2013).

IBs are characterized by substantial differences compared to conventional ones, especially as far as deposit agreements are concerned. From the liabilities side, the principle of profit and loss sharing (PLS) is applied through profit sharing investment accounts (PSIA), which are specific to IBs. Unlike CBs deposits, the contractual relationship between IBs and investment account holders (IAH), i.e. the PSIA holders called mudarabah, is based on the concept of PLS. IBs share their profits or loss with these account holders. Because of this quasi equity, IBs are expected to take lower risks in comparison to their peer counterparts. Hence, changes in the capital structure of IBs may not end up stimulating effects which are identical to those expected in the conventional system (i.e., lower risk exposure, although this needs to be verified in our context).

Our paper contributes to the related literature in three ways. First, we allow for a fourth factor - the business model, which is known to affect bank risk (Berger et al., 2010; DeAngelo and Stulz, 2015). To do so, we compare conventional and Islamic banks, the latter as a proxy for a banking system that is substantially different. DeAngelo and Stulz, (2015) offer a comparison of regulated and unregulated (shadow) banks and conclude that the business model (most notably through regulatory leverage limits) of the former impedes their ability to compete with the latter. Even though this may be an extreme example as all banks in our sample are regulated, there is a substantial literature highlighting the distinctiveness of conventional and Islamic banks with respect to financial profile (Olson and Zoubi, 2017, 2008), profitability and asset growth (Hasan and Dridi, 2011), asset quality and capitalisation (Beck et al., 2013), technical efficiency (Johnes et al., 2014) cost efficiency (Saeed and Izzeldin, 2016), credit risk (Abedifar et al., 2013), insolvency risk (Čihák and Hesse, 2010), failure risk (Pappas et al., 2017), loan default rates (Baele et al., 2014) and accounting practices (Elnahass et al., 2014) among

and the markedly different regulatory environments between EU and US (Altunbas et al., 2007). An updated examination of this triple-relationship in US context (as (Altunbas et al., 2007) have highlighted) might be useful direction for future research. ${ }^{4}$ Islamic law (Shariah) lays down a set of well-defined rules governing economic behavioural relationships. In addition the prohibition of interest (the Arabic term is Riba), there are rules covering individual and property rights; buyer and seller behaviour in the market; the right and enforce ability of contracts; and the role of the state. For descriptions of the Islamic economic system, see Mirakhor (1987), “The Economic System in an Islamic Society” Middle East Insight (August/September 1987): 32-45; and Pryor (1985), "The Islamic Economic System” Journal of Comparative Economics, 197-223. 
others. ${ }^{5}$ Second, with the exception of slight similarity with the studies by Alam (2012) and Bitar (2016) and Bitar (2018), this is the first study to examine the triple-relationship between bank risk, capital and efficiency for Islamic banks. Third, we examine the triple relationship between bank risk, capital and efficiency for a worldwide sample of banks.

In this paper we examine the triple-relationship between bank risk, capital and efficiency for conventional and Islamic banks, using data over the 2000 - 2012 period from 14 countries. We investigate insolvency risk and credit risk, which are proxied by the z-score and Loan Loss Provisions / Total Loans respectively. Capitalisation is proxied by the ratio of Equity to Assets. We estimate both cost and profit efficiency using stochastic frontier analysis similar to (Fiordelisi et al., 2011). Our system of three equations is subsequently estimated using the Seemingly Unrelated Regression (SUR) method that allows for simultaneity between the dependent variables.

We find that the capitalisation response to increases in insolvency risk is more pronounced for Islamic banks but has an approximately five-times smaller effect on risk mitigation compared to conventional banks. Higher cost efficiency is related to lower risk for conventional banks, but the opposite is true for Islamic banks. The link between cost efficiency and capitalisation attests to a substitutional effect for the case of conventional banks, but a complementary effect for Islamic banks. Our findings give new insights on the use of efficiency to gauge capital requirements for financial institutions and are particularly relevant for regulators and policy makers in countries where both bank types operate. Our results are confirmed through a series of robustness tests.

The rest of the paper is organised as follows. Section 2 presents the related literature and theoretical framework. Sections 3 and 4 present the methodology and data respectively. Section 5 presents and discusses the results. A final section concludes and presents the study implications.

\section{Theoretical Framework and Related literature}

\subsection{Theoretical framework}

\subsubsection{CB- IB Structural Differences \& Implications on Risk-Capital-Efficiency Behaviour}

The application of PLS through PSIA in IBs is adequate in rendering the operations of two models, IBs and CBs, distinguishable. However, despite these structural differences, CBs and IBs need to fulfil minimum regulatory capital requirements. Under the PLS scheme, IAH do not have the same rights as depositors or shareholders, but they are required to absorb any losses on assets, except the cases of negligence or misconduct by the bank. By implication (Archer and Karim, 2009), PSIA are not insured accounts, or capital certain. Rather, they are treated as investment products. Thus, if the IBs pay a lower return to PSIA holders than the rate paid by CBs or pass some losses to these depositors, they may withdraw their deposits from the IBs. Thus there may be a greater risk of deposit withdrawal for IBs than for CBs (Sundararajan and Errico, 2002). Specially, for small IBs this risk is higher and thus more problematic. To manage this risk IBs forgo part of their profit share to pay competitive returns to mudarabah account holders (MAH). If IBs incur some loss, all that loss may be taken to the income accounts of IBs, which otherwise has to be shared with PSIA holders. This activity exposes the equity holders of IBs to displaced commercial risk; defined by the Islamic Financial Services Board, IFSB

\footnotetext{
${ }^{5}$ By contrast, (Altunbas et al., 2007) have differentiated their analysis for commercial, co-operative and saving banks only to find co-operative banks to be somewhat different with respect to their key research questions. However, we believe that differences between commercial, co-operative and saving banks are not as pronounced as between conventional and Islamic banks.
} 
(2011), as additional risk borne by shareholders of IBs due to volatility of returns over and above the normal risks when PSIA holders were to share the loss in accordance with mudarabah contract. In other words, shareholders of an IB are exposed to additional losses which pertain to the PSIA depositors. The fact that PSIA holders are considered as investors and do not enjoy the same guarantees as other depositors (current accounts and savings accounts holders), or as shareholders, raises a major problem of governance that could impact negatively on IBs efficiency, through bank managers' capital and risk decisions. In the reminder of this section we provide an overview of the main elements which may affect the risk-capital-performance relationship in IBs and CBs.

An important feature that may affect the way capital structure influences efficient risk undertaking is that IB financiers are subject to a double agency problem; they have imperfect information on bank returns on investments (Pellegrina, 2012). As agent, the bank is not liable for losses but shares the profits with the investment account holder. An incentive to maximize investments funded by the account holder and to attract more account holders than it has the capacity to handle, can lead to investment decisions that are riskier than the investment account holder is willing to accept. Such "incentive misalignment", in the context of asymmetric information and moral hazard, may lead to higher displaced commercial risk, which necessitates higher capital requirements (Van Greuning and Iqbal, 2008; Visser, 2009).

In light of what is discussed above, monitoring is likely to be a main impetus behind the possible behavioural differences between IBs and CBs in terms of specific effect of capitalization on risk. In fact, since depositors in IBs share in risk, they could be pushed towards exerting tighter oversight over bank management compared to what occurs in traditional banks (Čihák and Hesse 2010). This should in principle result in an overall intensified monitoring activity, also sustained by higher interest alignment between stockholders and depositors (Jensen and Meckling, 1976). This may eventually limit managers' risk taking exposure. On the other hand, the shareholders' oversight on managerial actions could be mitigated by the fact that the former have a greater incentive to delegate it to other concerned agents (i.e., depositors) (Pellegrina, 2012).

Another element driving potential differences between IBs and CBs is the capability of rewarding fixedreturn investors. The use of debt is relevant to agency cost in several ways (Pellegrina, 2012). First, promised interest payments to debt holders decrease free cash flow available for investment (Harvey et al., 2004; Jensen, 1986; Stulz, 1990). This decrease in free cash flow also helps in curtailing overinvestment problem (Harvey et al., 2004; D'Melloand Miranda, 2010). Second, higher leverage may reduce agency costs through the monitoring activities by debt holders (Ang et al., 2000). Third, greater financial leverage may affect managers and reduce agency costs through the threat of liquidation, which may cause managers to lose reputation salaries, perquisites, etc. (Grossman and Hart, 1982; Williams, 1987).

The role played by efficiency on the capital-risk channel in IBs can be explained in the light of regulators enforcement upon banks to increase the amount of capital with the amount of risk taken; Gropp and Heider (2010) and Altunbas et al., (2007) referred to this positive relationship between capital and risk as the 'regulatory hypothesis'. Holding additional capital buffers above the regulatory minimum for banks with higher levels of risk could be (a) aimed to avoid the costs associated with having to issue fresh equity at short notice (Ayuso et al., 2004; Peura and Keppo, 2006) (b) due to efficient market monitoring from markets when capital positions are deemed inadequate (Calomiris and Kahn, 1991; Berger, 1995). Another reason for well-capitalized banks to take on more risk is that they are more remote from insolvency and can make use of riskier assets which yield a higher expected return. 
In the framework of the regulatory hypothesis, capital and risk are also likely to be influenced by the level of efficiency of the banking firm. From a regulatory perspective, and other things being equal, regulators may allow an efficient firm with better management probably more room for leverage. On the other hand, from a moral hazard point of view, a less efficient firm may be tempted to take on higher risk to compensate for the lost returns. Efficiency could, in turn, be also affected by the level of bank risk (Berger and De Young, 1997). For instance, managers who are inefficient at assessing and monitoring loans are not likely to be underperforming? Finally, a bank may choose to maximize shortterm profits by reducing the funds devoted to allocating and monitoring loans. This, other things being equal, would boost both efficiency and risk measures, producing (in the short-term) a positive relationship between risk and efficiency. Prior literature examining the determinants of banking risk takes into account the fact that capital and risk are both determined contemporaneously (Shrieves and Dahl, 1992; Jacques and Nigro, 1997; Rime, 2001). Also capital and risk may also be simultaneously determined by the level of efficiency of the banking firm (Kwan and Eisenbeis, 1997; Hughes and Moon, 1997; Hughes and Mester, 1998). The implication of this hypothesis remains debatable in the case of IBs. Given the quasi-equity of IBs in the form of mudarabah saving and investment (S\&I) deposits, an IB's asset portfolio is heavily biased towards short-term/low-risk financing. Thus, capital adequacy in IBs provides them with an extra line of protection and risks are lower but it can negatively affect the efficiency of these banks. Thus, if the capital structure of CBs is based on leverage instead of equity, then free cash flow will be lower, subsequent to which risk will decrease as well. However, compared to CBs, less capitalized IBs are less inclined to reduce free cash flow since they are allowed to shift part of the risk on depositors (Hesse at al., 2008; Iqbal and Llewellyn, 2002; Sundararajan and Errico, 2002). For this reason, lower capitalization in IBs may not decrease risk taking to the same extent as for CBs. Our objective is to add to the empirical literature by providing new insights into the relationship between capital, risk, and efficiency.

\subsection{Related literature}

Recent economic crises have revealed the importance of bank regulations to hedge against the high risk attributed to imbalances in banks' balance sheets. Capital regulation is one of the important tools that are used to prevent banks from failure (Carbó-Valverde and Sánchez, 2013; Levine and Zervos, 1998; Stiglitz, 2000). The examinations of the effect of bank capital regulations on bank behaviour have been focused on the US. These early studies were mainly concerned with whether the existence of flat-rate deposit insurance induced banks to take on excessive risk. They emphasize the importance of controlling other factors to limit risk-taking, such as the deposit insurance flat fee rate or the level of nominal interest rate (Marcus, 1983).

The new wave of studies focusing on the relationship between risk and capital started after the introduction of the 1988 Basel Accord on international bank capital. The Basel Accord ${ }^{6}$ is, perhaps, the single most important regulatory framework that banks need to abide by, which attempts to control bank risk through capital adequacy requirements. ${ }^{7}$ Both the theoretical and empirical literature on the impact of capital regulation has produced a variety of conclusions concerning the efficiency and the riskadjustment behaviour of banks. On the one hand, regulations serve as prudential measures that mitigate the effects of economic crises on the stability of the banking system. On the other hand, excessive regulations may increase the cost of intermediation and reduce the profitability of the banking industry.

\footnotetext{
${ }^{6}$ We collectively refer to all Basel accords here. For a history on the Basel Accords we direct you to https://www.bis.org/bcbs/ history.htm

${ }^{7}$ Capitalisation requirements have been consistently featured in Basel Accords. Basel II further introduced provisions for market risk (e.g., Value at Risk estimates), while Basel III regulates liquidity risk too.
} 
Financing decisions made by many banks have been influenced by the regulatory minimum capital constraints (Wall and Peterson, 1988; Shrieves and Dahl, 1990). Empirical studies of the effectiveness of capital adequacy regulations and the relationship between increases in banking capital and risk tend to find that capital regulation in banking has been effective in increasing capital ratios without substantially shifting their portfolio and off-balance sheet exposure towards riskier assets (see e.g., Shrieves and Dahl, 1992, Editz et al., 1997; Rime, 2001).

A number of studies have examined the triple relationship between risk, capital and efficiency in a unified framework (Altunbas et al., 2007; Berger and DeYoung, 1997; Deelchand and Padgett, 2009; Dong et al., 2017; Fiordelisi et al., 2011; Hu and Yu, 2015; Kwan and Eisenbeis, 1997; Tan and Floros, 2013; Williams, 2004). Although there appears to be consensus on the choice of the capitalisation proxy with the equity to assets ratio, this is not the case for the risk proxy or the efficiency estimate. Several studies have used the non-performing loans to total loans (NPL/TL), see for example (Berger and DeYoung, 1997; Dong et al., 2017; Fiordelisi et al., 2011; Kwan and Eisenbeis, 1997). Non-performing loans to total loans is less susceptible to managerial discretion compared to loan loss provisions and/or reserves (LLP/TL, LLR/TL), see for example the studies of (Altunbas et al., 2007; Deelchand and Padgett, 2009; Tan and Floros, 2013; Williams, 2004) which opt for these proxies mainly driven by data availability issues. A few studies have also used other measures such as the z-score (Tan and Floros, 2013), expected default (Fiordelisi et al., 2011) and risk-weighted assets to total assets ( $\mathrm{Hu}$ and $\mathrm{Yu}$, 2015). The country focus is mainly developed economies, such as the US (Berger and DeYoung, 1997; Kwan and Eisenbeis, 1997), the EU (Altunbas et al., 2007; Fiordelisi et al., 2011; Williams, 2004) and Japan (Deelchand and Padgett, 2009). Developing countries have also been the focal point of (Tan and Floros, 2013), (Dong et al., 2017) for China and (Hu and Yu, 2015) for Taiwan.

For the system of equations, two-stage least squares (2SLS) and three-stage least squares (3SLS) has been adopted in (Deelchand and Padgett, 2009; Hu and Yu, 2015; Kwan and Eisenbeis, 1997; Tan and Floros, 2013). Alternative techniques include GMM (Dong et al., 2017; Fiordelisi et al., 2011), SUR estimation (Altunbas et al., 2007) and Vector-autoregressive / Granger causality approach (Berger and DeYoung, 1997; Williams, 2004).

We review some of the results with the broadest of strokes. A certain support is found for the "bad management" hypothesis, whereby lower efficiency leads to higher risk (Berger and DeYoung, 1997; Fiordelisi et al., 2011; Williams, 2004). Support for the "skimping hypothesis", whereby higher efficiency is associated with higher risk is found in (Altunbas et al., 2007) and (Tan and Floros, 2013). The moral hazard hypothesis is verified in the studies of (Deelchand and Padgett, 2009) and (Tan and Floros, 2013). Under the moral hazard hypothesis capital and risk are inversely related; however, efficiency has a catalytic role. Specifically, the moral hazard hypothesis holds for the efficient banks (Deelchand and Padgett, 2009), while for the inefficient ones a positive link between capital and risk is verified, which attests to the "regulatory hypothesis".

The existing literature on IB, specifically on the linkage between risk, capital and efficiency is sparse. Academics have however focused instead on analysing the factors influencing bank risk-taking and efficiency and analysing the differences in stability between CBs and IBs. Some of these academics briefly touch upon the aspect of bank capital and its effect on the performance of IBs.

The empirical work done which provides cross country evidence on the financial stability of CBs and IBs is fairly comparable. Čihák and Hesse (2010) compare the stability of Islamic versus conventional banks, using data from 20 member countries of the OIC between 1993 and 2004. They find that small 
IBs are more stable than similar-sized CBs. Large IBs, however, are less stable. Abedifar et al. (2013) find no significant difference between the two banking sectors with respect to the insolvency risk. Their finding on credit risk is mixed, varying according to which proxy for credit risk is used. For instance, IBs have lower credit risk than CBs, specifically in the case of highly leveraged banks operating in predominantly Muslim countries. Also, small IBs exhibit greater stability as they are more capitalized. However, they found no significant difference between large IBs and CBs.

Only a few recent studies (Alam, 2012; Bitar, 2016; Bitar 2018) have tried to assess the impact of Basel III requirements on the efficiency and risk for IBs. Alam (2012) examines the conflicted relationship between banking regulations, risk, and efficiency between CBs and IBs. Using data on capital, liquidity, risk and efficiency, he argues that IBs are more adaptable to regulatory requirements than CBs. However a similar relationship is observed for both IBs and CBs in that a negative relationship between capital buffers and risk is observed for both bank categories and a positive relationship with bank efficiency confirming the results of Pasiouras (2008), Chortareasa et al. (2012), and Barth et al. (2013). Bitar et al. (2016) examine the impact of the Basel III regulatory framework on the efficiency of IBs and CBs using conditional quantile regressions. They find that IBs are significantly more efficient than conventional banks and Basel III requirements for higher capital and liquidity are negatively associated with the efficiency of IBs while the opposite is true for financial leverage. Their results show that the impact of capital requirements on bank performance is more pronounced for too-bi-to-fail banks. Furthermore, they find that higher capital and liquidity positions resulted in better efficiency for CBs than IBs during the subprime crisis. Bitar et al. (2018) examine whether the imposition of higher capital ratios is effective in reducing risk and improving the efficiency and profitability of banking institution. They use various proxies for capital ratios to determine which kinds of capital are most effective in enhancing banking system stability and performance. Their findings shed an important light on the application of Basel III in that the weighting methodologies used for calculating risk-based capital ratio can have negative implication specifically for highly liquid banks as imposing higher capital ratios may have a negative effect on the efficiency and profitability of highly liquid banks.

We go a step further in analysing capital, risk and efficiency simultaneously so as to explain the behavioural difference between CBs and IBs with regard banks attaining efficiency in light of its effect on capital ratio and risks. In this study, we adopt an approach taken by Deelchand and Padget (2009) and Heid et al. (2003). These researchers treat efficiency, risk, and capital simultaneously.

\section{Methodology}

This section discusses the modelling framework adopted in this paper. We follow the studies of (Altunbas et al., 2007; Berger and DeYoung, 1997; Deelchand and Padgett, 2009; Dong et al., 2017; Fiordelisi et al., 2011; Hu and Yu, 2015; Kwan and Eisenbeis, 1997; Tan and Floros, 2013; Williams, 2004) in specifying a system of three equations; one for each variable of interest, namely risk, capital and efficiency. The system of equations is estimated using the Seemingly Unrelated Regression (SUR) approach of (Zellner, 1962), in line with (Altunbas et al., 2007). The main advantages of the SUR estimation technique are that i) it allows for simultaneity between the dependent variables, ii) it is an efficient estimation technique that uses contemporaneous correlation information among error terms of the equations (Moon and Perron, 2005). The system of the three equations is given below:

$$
\begin{array}{rl}
\text { RISK }_{i j t}=\beta_{0}+\beta_{1} & C \\
& +P_{i j t}+\beta_{2} E_{7} G D F_{i j t}+\beta_{3} \text { Size }_{i j t}+\beta_{4} T P B R_{i j t}+\beta_{5} N L T A_{i j t}+\beta_{6} M C O N F_{j t}+\gamma_{0} I B+\gamma_{1} I B \times C A P_{i j t}+\gamma_{2} I B \times E F F_{i j t} \\
& +\gamma_{3} I B \times \text { Size }_{i j t}+\gamma_{4} I B \times T P B T_{i j t}+\gamma_{5} I B \times N L T A_{i j t}+\gamma_{6} I B \times C O N C_{j t} \\
& +\gamma_{7} I B \times G D P G R_{j t}+\gamma_{8} I B \times I N F_{j t}+\varepsilon_{i j t}
\end{array}
$$




$$
\begin{aligned}
& C A P_{i j t}=\beta_{0}+\beta_{1} R I S K_{i j t}+\beta_{2} E F F_{i j t}+\beta_{3} \operatorname{Size}_{i j t}+\beta_{4} T P B T_{i j t}+\beta_{5} R O A_{i j t}+\beta_{6} C_{O N C_{j t}} \\
& +\beta_{7} G D P G R_{j t}+\beta_{8} I N F_{j t}+\gamma_{0} I B+\gamma_{1} I B \times R I S K_{i j t}+\gamma_{2} I B \times E F F_{i j t} \\
& +\gamma_{3} I B \times \text { Size }_{i j t}+\gamma_{4} I B \times T P B T_{i j t}+\gamma_{5} I B \times R O A_{i j t}+\gamma_{6} I B \times C O N C_{j t} \\
& +\gamma_{7} I B \times G D P G R_{j t}+\gamma_{8} I B \times I N F_{j t}+\varepsilon_{i j t} \\
& \begin{array}{rl}
E F F_{i j t}=\beta_{0}+\beta_{1} & R I S K_{i j t}+\beta_{2} C_{A P P_{i j t}}+\beta_{3} \text { Size }_{i j t}+\beta_{4} T P B T_{i j t}+\beta_{5} O B S T A_{i j t}+\beta_{6} C_{O N O} C_{j t} \\
& +\beta_{7} G D P G R_{j t}+\beta_{8} I N F_{j t}+\gamma_{0} I B+\gamma_{1} I B \times R I S K_{i j t}+\gamma_{2} I B \times C A P_{i j t} \\
& +\gamma_{3} I B \times S_{i z e_{i j t}}+\gamma_{4} I B \times T P B T_{i j t}+\gamma_{5} I B \times O B S T A_{i j t}+\gamma_{6} I B \times C O N C_{j t} \\
& +\gamma_{7} I B \times G D P G R_{j t}+\gamma_{8} I B \times I N F_{j t}+\varepsilon_{i j t}
\end{array}
\end{aligned}
$$

where the subscripts $i, j$, and $t$ index banks, countries and years respectively and $\varepsilon_{i j t}$ denotes the stochastic error term. RISK is denotes the insolvency risk (proxied by the z-score). CAP denotes the capitalisation and is proxied by the Equity/Assets ratio. EFF denotes the cost efficiency. IB denotes the Islamic banking dummy which takes the value of 1 for an Islamic bank, zero otherwise. The following bank-level control variables are included: Bank size, as the natural logarithm of total assets; profitability, proxied by ROA; the tax to pre-tax profit ratio (TPBT); liquidity proxied by net loans to total assets (NLTA); Off-balance sheet items/Total Assets. As macroeconomic and market structure controls we include the concentration ratio of the three largest banks in terms of assets in a given country and time (CR3), the annual real GDP growth rate (GDPGR) and the annual inflation rate (INFLATION).

\subsection{Efficiency estimation}

Our choice of cost efficiency is motivated by the prior literature. First, cost efficiency is the preferred efficiency measure in most studies that investigate the triple relationship between capital, risk and efficiency (Altunbas et al., 2007; Berger and DeYoung, 1997; Deelchand and Padgett, 2009; Dong et al., 2017; Fiordelisi et al., 2011; Hu and Yu, 2015; Kwan and Eisenbeis, 1997; Williams, 2004). Second, there is more consensus on the comparative studies between Islamic and conventional banks on cost efficiency as opposed to technical efficiency.

In this study, we estimate cost efficiency using Stochastic Frontier Analysis (SFA), and apply a translog functional form as it is flexible, easy to estimate and permits the imposition of homogeneity (Coelli and Perelman, 2000). We opt for an SFA estimation over a Data Envelopment Analysis (DEA) alternative as it allows for stochastic errors and takes into account the panel nature of our data. Besides, SFA seems to be the preferred estimation technique for efficiency in the literature that investigate the triple relationship between capital, risk and efficiency. ${ }^{8}$ We follow the intermediation approach to modelling financial institution behaviour as proposed by (Sealey and Lindley, 1977) and assumes that banks act as intermediaries between savers and borrowers. The approach has been adopted in (Berger and Mester, 1997; Karas et al., 2010; Mamatzakis, 2015; Weill, 2003) in estimating conventional banking efficiency, and in (Abdul-Majid et al., 2010; Johnes et al., 2014; Sufian and Noor, 2009) in IB/CB comparative efficiency estimation settings. For the choice of inputs and outputs we are guided by the

\footnotetext{
${ }^{8}$ The intermediation approach assumes that banks act as intermediaries between savers and borrowers and posits total loans and securities as output, whereas deposits along with labour and physical capital are defined as inputs. This approach reflects the way IBs operate as they rely on profit-sharing contracts, which involve equity participation principle with depositors. IBs can therefore be seen as intermediating savers and investors by transforming deposits into earning assets, rather than as producers of services and loans
} 
existing literature and opt for a setting with two outputs; namely net total loans $\left(y_{1}\right)$ and other earning assets $\left(y_{2}\right)$. For Islamic banks who do not issue loans per se, the convention is that PLS instruments are used instead, see for example (Johnes et al., 2014). The banks make use of three inputs; physical capital $\left(x_{1}\right)$, labour $\left(x_{2}\right)$ and financial capital $\left(x_{3}\right)$. The price of physical capital $\left(w_{1}\right)$ is given by the ratio of non-interest expenses to fixed assets. The price of labour $\left(w_{2}\right)$ is given as the ratio of personnel expenses to total assets. The price of financial capital $\left(w_{3}\right)$ is computed by dividing interest expenses by total funding. Total cost is calculated as interest and non-interest costs divided by total assets. In our SFA approach we incorporate country specific variables directly into the cost efficiency model, which has been cited critical for cross-country studies by incorporating the environmental economic effect in the estimated frontier (Carvallo and Kasman, 2005; Fries and Taci, 2005). To empirically implement the cost frontier, the translog form of the cost function to be estimated is specified as follows:

$$
\begin{aligned}
\ln C_{i j t}=\alpha_{0}+ & \sum_{m=1}^{2} \alpha_{m} \ln w_{m, i j t} \\
& +\sum_{s=1}^{2} \beta_{s} \ln Y_{s, i j t}+1 / 2\left[\sum_{m=1}^{2} \sum_{n=1}^{2} \alpha_{m, n} \ln w_{m, i j t} \times w_{n, i j t}\right. \\
& \left.+\sum_{s=1}^{2} \sum_{r=1}^{2} \beta_{s, r} \ln Y_{s, i j t} \times Y_{r, i j t}\right] \\
& +\sum_{m=1}^{2} \sum_{s=1}^{2} \varphi_{m, s} \ln w_{m, i j t} \times Y_{s, i j t}+v_{i j t}+u_{i j t}
\end{aligned}
$$

where subscripts $i, j, t$ denote banks, countries and time respectively, $\ln C_{i j t}$ denotes the natural $\log$ of total costs, $\ln w_{m, i j t}$ the natural $\log$ of input prices, $\ln Y_{s, i j t}$ is the natural $\log$ of outputs, $\alpha, \beta, l$, and $\varphi$, are the parameters to be estimated, $v_{i j t}$ is the stochastic error term and $u_{i j t}$ is the inefficiency term. Standard linear homogeneity and symmetry restrictions in all quadratic terms are imposed in accordance with economic theory, while we also include country, year and ownership dummies to capture any differences across countries. The linear homogeneity conditions are imposed by normalizing Total Cost $(C)$, price of financial capital $\left(w_{3}\right)$ and price of labour $\left(w_{2}\right)$, by the price of price of physical capital $\left(w_{1}\right)$. The translog SFA function further includes time and country dummies to control for country heterogeneity and shifts in the frontier.

In this model we allow for the cost inefficiency term $u_{i j t}$ to have a systematic component $Z_{i j t}$ associated with exogenous macroeconomic and market structure variables, and a random component $e_{i j t}$, in line with (Saeed and Izzeldin, 2016). The macroeconomic variables used in this step are: i) GDP per capita, ii) real GDP growth, iii) degree of monetization, iv) stock market capitalisation, v) annual inflation rate, and vi) population density. For market structure variables we opt for the concentration ratio of the three largest banks in each country/year. Specifically, $u_{i j t}$ is given as:

$$
u_{i j t} \equiv Z_{i j t} \gamma+e_{i j t}
$$

where $\gamma$ is a vector of parameters to be estimated.

\section{Data}

This section describes, the data coverage and sources used for this study, the dependent variables of the system of equations, the explanatory variables used and presents key descriptive statistics. 


\subsection{Data coverage and sources}

The data are drawn predominantly from the balance sheets and income statements of the Bureau van Dijk Bankscope database for the period 2000 to 2012 and across 14 countries. The countries are: Bahrain, Bangladesh, Egypt, Indonesia, Iran, Jordan, Kuwait, Malaysia, Pakistan, Qatar, Saudi Arabia, Tunisia, Turkey and the UAE. A small number of observations for missing periods were obtained from the annual reports of individual banks. Our final sample consists of an unbalanced panel of 2,757 bankyear observations for 245 banks. Of these, 65 are Islamic and 180 are conventional banks, which means that nearly $26 \%$ of our sample coverage relates to Islamic banks - similar or higher than previous studies (Abdul-Majid et al., 2010; Al-Jarrah and Molyneux, 2006; Beck et al., 2013; Čihák and Hesse, 2010; Srairi, 2010). Table 1 presents the distribution of bank observations by operational mode and country.

[Table 1 around here]

Islamic windows are excluded from this subsample due to supervisory issues and capital adequacy requirements raised rendering them substantially different from those raised for full-fledged Islamic financial institutions (IFSB, 2011). Furthermore, we include banks for which at least five years of data are available over the sampled period. The minimum requirement of five years helps to distinguish reliably between random noise and bank inefficiency in the errors of estimated cost functions to calculate cost and profit efficiency (Fries and Taci, 2005). After these restrictions, the sample countries host about $77 \%$ of the worldwide Islamic banking assets.

Macroeconomic variables include the gross domestic product (GDP), degree of monetization (MONET), GDP per capita (GDPPC), real GDP growth (GDPG), stock market capitalisation (MKTGDP), annual inflation rate (INFLATION) and density of population (DPOP). All monetary values are convereted to real 2010 prices using each country's consumer price index (CPI). Data source for macroeconomic data are IMF's International Financial Statistics and the World Bank. Market structure variables, such as market concentration (CR3), are calculated using Bankscope data.

\subsection{Dependent variables}

We proxy insolvency risk (IR) using the z-score, which is a widely used proxy for this purpose (Abedifar et al., 2013; Boyd and Runkle, 1993; Čihák and Hesse, 2010; Lepetit et al., 2008). In principle the Z-score calculates the number of standard deviations that the bank's return on assets (ROA) must fall below its mean in order to deplete equity. The Z-score increases with higher profitability and capitalization levels and decreases with volatile earnings. Therefore, high values of the Z-score denote financially stable banks bearing a low probability of default. In practice, there are several definitions with (Mare et al., 2017) providing a nice review. In our study we use the (Cihák and Hesse, 2007) variant, which is given by:

$$
Z-\text { score }_{t}=\frac{\frac{\text { Equity }_{t}}{\text { Assets }_{t}}+R O A_{t}}{\sigma\left(R O A_{T}\right)}
$$

where $t=1, \ldots, T$, ROA is the Return on Assets and $\sigma(\cdot)$ denotes the standard deviation operator.

The (Cihák and Hesse, 2007) measure of the Z-score considers only the last period value for the Equity/Assets and the ROA, while it computes $\sigma\left(R O A_{T}\right)$ over the whole sample period. In this way it 
is better suited for an unbalanced panel. The z-score can be equally applied to Islamic and conventional banks since these operate in the same environment and face the same risks in case they run out of capital. Another popular measure of insolvency risk is the Distance-To-Default, which uses stock price data to measure the volatility in the economic capital of the bank, see (Saeed and Izzeldin, 2016). However, as most Islamic banks are not listed in a stock exchange, market price data are not available.

Capitalisation is proxied by the ratio of equity to assets and measures the bank's financial cushion to absorb financial losses. Efficiency is the dependent variable of Equation (3) and refers to cost efficiency which is estimated using a stochastic frontier approach, as described in an earlier section.

\subsection{Explanatory variables}

Bank-specific variables include total assets (SIZE), as a key determinant of capitalisation, risk and efficiency. For example, large banks can be more efficient (Abdul-Majid et al., 2005; Miller and Noulas, 1996) because of the economies of scale and scope they can utilise. Large banks may also be less capitalised for reasons related to their ready access to interbank and/or capital markets, higher risk taking and/or higher efficiency (Hughes and Mester, 1998; Peltzman, 1970). Banks are also subject to direct taxation (e.g., corporate tax), which is proxied by the tax to pre-tax ratio (TPBT). Although the tax rate on corporate profit is not a choice for banks, yet, the bank management should be able to structure its portfolio to minimize tax. Since consumers face an inelastic demand for banking services, it is expected that most banks are able to pass the tax burden to their customers. A positive relationship between taxation and profitability is verified in (Bashir, 2003; Demirguc-Kunt and Huizinga, 1999) for banks in Middle East and (Jiang et al., 2012) for banks in Hong Kong. As profitability is directly related to financial risk, capitalisation and efficiency, as explained in an earlier section, we control for differences with respect to tax environment.

The next set of explanatory variables enter specific equations. For the risk equation (Eq1), a measure of liquidity is included as rapid loan growth may increase risk which may impact adversely on capital and bank efficiency. Our choice of liquidity proxy is the net loans to total assets (NLTA). Liquidity management is crucial to accommodate sudden decreases in liabilities and support expansion of the assets side of the balance sheet. Bank managers need to counterweigh the inverse relationship between liquidity and profitability, whereby extra liquidity comes at the cost of forgone investment opportunities, and the positive relationship between liquidity and financial stability, which is further emphasised in Basel III (Bordeleau and Graham, 2010; Bourke, 1989). With regards to liquidity management, Islamic banks have the additional challenge of limited access to interbank markets, which justifies in part their higher liquidity (Beck et al., 2013; Pappas et al., 2017). In the capitalisation equation (Eq2), we control for profitability using the return on assets (ROA). Profitability and capitalisation are strongly related as verified in earlier studies (Berger, 1995; Scholtens, 2000). The efficiency equation (Eq3) includes the ratio of off-balance sheet items to total assets (OBSTA) to control for off-balance sheet (OBS) activities that the bank may be using without adjusting their capital structure (e.g., loan commitments, standby letters of credit and commercial papers). The moral hazard hypothesis states that OBSTA activities increase bank risk; thus, leading to inefficiency.

Macroeconomic and market structure variables are also factored in the system of equations. Concentration (MCONC) can have positive or negative impact on bank performance. A strand of the literature suggests a positive relationship between concentration and banking performance (Bourke, 1989; Smirlock, 1985; Staikouras and Wood, 2004). This is plausibly linked to the 'quiet life' 
hypothesis and the greater the monopolistic power such banks would exhibit. On the other hand, certain studies report an inverse relationship between concentration and performance. For example, Ben Naceur and Goaied (2008) for Tunisia, and Karasulu, (2001) for Korea. Iannotta et al., (2007) suggests that concentration affects both banking risk and performance for a sample of European banks. Fiordelisi et al., (2011) also document an inverse relationship between risk and concentration that implies of bank risks being lower in concentrated markets, which is in line with the notion that competitive banking systems may be less stable of (Boyd and De Nicoló, 2005).

The annual GDP growth rate (GDPGR) captures the cyclical conditions of the macroeconomic environment. It is also expected to capture the implications for bank efficiency as demand for financial products depends on the level of economic activity. Several empirical studies (Demirgüç-Kunt and Maksimovic, 1998; Schure and Wagenvoort, 1999; Semih Yildirim and Philippatos, 2007) find that countries with higher GDP growth rate feature more efficient and stable banking institutions.

Inflation (INF) is an important determinant of banking performance. The findings of the relationship between inflation and bank performance are mixed. In general, high inflation rates are associated with high loan interest rates and high income. Empirical studies of Guru et al. (2002) for Malaysia and Jiang et al., (2012) for Hong Kong show that high inflation rates lead to higher bank profitability. However, the effect of inflation on banking performance depends on whether inflation is anticipated or not (Perry, 1992). If inflation is fully anticipated and interest rates are adjusted accordingly, there is likely to be a positive impact on profitability. Alternatively, unexpected inflation causes cash flow difficulties for borrowers, which can lead to premature termination of loan arrangements and precipitate loan losses. Indeed, if the banks are sluggish in adjusting their interest rates, there is a possibility that banks' costs may increase faster than bank revenue. Demirguc-Kunt and Huizinga (1999) notice that banks in developing countries tend to be less profitable in inflationary environments, particularly when they have high capital ratios. In addition, Hoggarth et al., (2001) also conclude that high and variable inflation may cause difficulties in planning and negotiating loans. The definitions of the variables are given in table 2

[Table 2 around here]

\subsection{Descriptive Statistics}

Table 3 presents descriptive statistics for the variables used in the efficiency estimation and the variables used in the main analysis, for the sample of all banks, Islamic banks and conventional banks. Islamic banks have lower z-score, on average, compared to conventional banks (16.86 versus 19.29), suggesting that they exhibit higher insolvency risk. Capitalisation of Islamic banks is higher than their conventional counterparts (19.84\% versus $11.02 \%$ ), a finding which is consistent with the literature (Beck et al., 2013). In terms of cost efficiency, the two bank types show no significant differences. Islamic banks are smaller than conventional banks as indicated by the average size $(92,447$ versus 111,466$)$; however the two bank types have similar profitability, as indicated by the ROA, and liquidity, as shown by the NLTA. However, conventional banks have significantly higher off-balance sheet activities $(51.60 \%$ versus $24.82 \%$ ) than Islamic banks, which may partially explain the lower risk profile of the latter.

[Table 3 around here] 


\section{Results}

Table 4 presents estimated coefficients and robust standard errors in parenthesis from the SUR estimation of the system of equations in section 4. The estimates of the risk equation that uses the $\mathrm{z}-$ score are shown as equation 1. Equation 2 presents the results for the equation related to capitalisation, whereas for cost efficiency equations the results are presented as equation 3 . Each equation comprises three models (labelled I, II and III) that allow for increasingly more variation between the two banking models. In particular, model I allows for a level shift in the dependent variables between Islamic and conventional banks, by including an Islamic bank binary variable. Variant II allows for unique sensitivities of the two banking models with respect to the triple-relationship variables (risk, capitalisation and efficiency), with variant III allowing for unique sensitivity to all bank-related and macroeconomic/market structure variables. In all cases this is achieved by appropriate interaction terms between the Islamic bank binary variable and the variables of interest. We are mindful of endogeneity in our analysis. We test the exogeneity of the regressors for each individual equation via the DurbinWu-Hausman test. Subsequently we perform the Breusch and Pagan (1980) test of independence of correlations across equations. The conclusion of both tests suggests that endogeneity is not an issue, and that the SUR estimation technique is appropriate in this context. ${ }^{9}$

[Table 4 around here]

\subsection{Risk / Capitalisation}

For both bank types, our results suggest an inverse and bi-directional relationship between insolvency risk and capitalisation. In particular through Model I in Equations 1 and 2 we have $\hat{\beta}_{\text {capital }}=18.808$ and $\hat{\beta}_{z \text {-score }}=0.647$ respectively. This gives prima facie evidence that higher capitalisation reduces risk exposure and offers an affirmation of the regulatory hypothesis, whereby capital should increase commensurably with the risk exposure of the bank. This result is in line with Fiordelisi et al., (2011) who also verify a bi-directional relationship for credit risk and capitalisation.

Allowing for a difference in the business model does not affect the inverse and bi-directional relationship between insolvency risk and capitalisation remains. However, the magnitude of the response for each bank type appears remarkably different. In particular through Model III in Equations 1 and 2 we have $\hat{\beta}_{\text {capital } \mid C B}=49.214$ and $\hat{\beta}_{z-\text { score } \mid C B}=0.574$ for conventional banks respectively, and $\hat{\beta}_{\text {capital|IB }}=9.75$ and $\hat{\beta}_{z-\text { score } \mid I B}=0.756$ for Islamic banks respectively. ${ }^{10}$ This suggests that despite the fact that capitalisation response to increases in insolvency risk is significantly more pronounced in the case of Islamic banks, the 'regulatory effect' is less effective. Even though Islamic banks increase their capitalisation by $27.5 \%$ more than conventional banks for each unit of risk they assume, any capitalisation increase on behalf of Islamic banks has an approximately five-times smaller effect on risk taking compared to conventional banks.

Overall, it appears that Islamic banks are more in line with the regulator's requirements about increasing capital commensurably with the risk exposure. However, the results also suggest that for controlling risk taking in Islamic banks, regulators may have to rely on alternative measures as capitalisation is not as effective as in conventional banks.

\footnotetext{
${ }^{9}$ Hence using instrumental variables or 2SLS approach is not appropriate due to the lack of endogeneity in the system.

${ }^{10}$ The effect of capitalisation on the z-score for Islamic banks is given as $\hat{\beta}_{\text {capital|IB }}=\hat{\beta}_{\text {capital }}+\hat{\beta}_{\text {IB } \times \text { capital }}=49.21-$ $39.46=9.75$
} 
The reason for this differentiated effect may be in part explained by the fact that Islamic banks have the necessary mechanisms that provide discipline and effective monitoring in place. Depositors and investment accountholders are incentivized to monitor performance, given the uncertainty in payouts that is achieved through the equity-type contractual agreements. The effectiveness of such mechanisms may be, in part, corroborated by the positive and significant coefficient on the Islamic bank binary variable in Equation 1, suggesting that this bank type is financially more stable. Besides, the use of investment accountholders resembles the use of subordinated debt as a way to monitor bank activities through increased withdrawal risk, which has received some support in the conventional banking system (Wall 1989). This is corroborated further in Altunbas et al., (2007) who suggest a potential positive implication of subordinated debt on the bank's alignment with the regulatory hypothesis. However, despite this more pronounced response of Islamic banks, the increase of capitalisation is not as effective in reducing banking risk as for the case of conventional banks.

The effect from capitalisation to risk represents the unintended consequences of regulatory actions, where banks respond to the increased capitalisation requirements by assuming more risk, to compensate for the forgone benefits of the leverage (Kahane, 1977). The fact that this effect is significantly less pronounced (about five-times) for Islamic banks might be plausibly attributed to their significantly higher capitalisation, see (Beck et al., 2013; Pappas et al., 2017) and Section 4.4 of this paper) than conventional banks. Often banks operate in excess of the regulatory capitalisation requirements to avoid costs associated with a swift re-capitalisation (Peura and Keppo, 2006). Therefore, the furthest away the bank's capitalisation from the minimum regulatory limit, the smaller the unintended consequences of regulatory actions are expected to be, and capitalisation's effectiveness in controlling risk might be reduced.

\subsection{Efficiency/Risk}

For both bank types, our results suggest an inverse and bi-directional relationship between insolvency risk and cost efficiency. In particular through Model I in Equations 1 and 3 we have $\hat{\beta}_{\text {eff }}=1.722$ and $\hat{\beta}_{z-\text { score }}=0.335$ respectively. These results offer support for the 'bad (good) management' and 'bad (good) luck' hypotheses respectively. Specifically, lower (higher) cost efficiency is associated with higher (lower) risk taking. Likewise, higher (lower) risk taking reduces (increase) cost efficiency. This result is in line with (Berger and DeYoung, 1997; Fiordelisi et al., 2011; Williams, 2004) who also find evidence in support of these hypotheses for their respective samples of US/EU banks.

Allowing for a difference in the business model does not affect the inverse relationship from risk to cost efficiency. However, the response of risk to efficiency is now a positive one. In particular through Model III in Equations 1 and 3 we have $\hat{\beta}_{e f f \mid C B}=5.214$ and $\hat{\beta}_{z-s c o r e \mid C B}=0.350$ for conventional banks respectively, and $\hat{\beta}_{\text {capital|IB }}=-9.787$ and $\hat{\beta}_{z-\text { score } \mid I B}=0.178$ for Islamic banks respectively. This suggests that for both bank types a reduction in risk is beneficial for cost efficiency, albeit the effect is about $67.6 \%$ less pronounced for the Islamic banks. Conversely, an increase in cost efficiency is regarded differently by the two bank types with regards to their risk levels. In particular, higher cost efficiency is related to lower risk for conventional banks but higher risk for Islamic banks.

Our results for conventional banks verify previous findings on EU commercial banks whereby it is claimed that efficient banks should be granted with a softer regulatory touch due to their superior management abilities (Altunbas et al., 2007). However, this claim receives little support for the case of Islamic banks, where support of the 'skimping hypothesis' exists. Hence, the most efficient Islamic 
banks are expected to bear higher risk. The mixed results in the case of Islamic banks may relate to their being a more heterogeneous sample and/or non-linearities in the cost efficiency/risk relationship. Specifically, it may be plausible that the risk profile of Islamic banks changes markedly across the cost efficiency spectrum and/or there are differences in the implementation of Islamic banking across the countries, as suggested in (Johnes et al., 2017).

\subsection{Capitalisation / Efficiency}

For both bank types, our results suggest an inverse and bi-directional, inverse relationship between capitalisation and cost efficiency. In particular through Model I in Equations 2 and 3 we have $\hat{\beta}_{\text {eff }}=$ -2.232 and $\hat{\beta}_{\text {capital }}=-16.386$ respectively. The results suggest that higher cost efficiency is associated with lower capitalisation and vice versa. There seems to be a substitution effect between the two metrics.

Allowing for differences in the business models does not affect the inverse relationship from capitalisation to cost efficiency. However, the response of capitalisation to cost efficiency is now a positive one. In particular through Model III in Equations 2 and 3 we have $\hat{\beta}_{e f f \mid C B}=-6.498$ and

$\hat{\beta}_{\text {capital } \mid C B}=-39.748$ for conventional banks respectively, and $\hat{\beta}_{\text {eff } \mid I B}=8.209$ and $\hat{\beta}_{\text {capital } \mid I B}=$ -5.859 for Islamic banks respectively. These results further corroborate the substitution effect between capitalisation and cost efficiency for conventional banks. However, the results for Islamic banks suggest that higher cost efficiency is associated with increased capitalisation; a complementary relationship.

It has been argued that efficient banks should be given more flexibility from the regulator with regards to their leverage levels due to their superior management (Altunbas et al., 2007; Hughes et al., 2001). The conventional banks in our case seem to verify this "regulatory efficiency aware hypothesis" as more efficient banks have lower capitalisation. Thus, capitalisation and cost efficiency may be substitutes in controlling bank risk taking. Consequently, efficient banks may have higher flexibility to increase their leverage, possibly putting forward their superior management (reflected upon efficiency) that could justify their ability to assume higher risks. By contrast, Islamic banks do not conform to this hypothesis as more efficient banks have higher capitalisation too.

This key difference between the two banking models lies, in part, to their capitalisation profiles, where the Islamic banks' preclusion from debt instruments limits their ability to leverage to similar extends as conventional banks. Higher levels of cost efficiency are pursued by both banks. However, each bank reaps the benefits in a different way. For conventional banks, higher efficiency is desirable as it manifests in flexibility to increase leverage, assume higher risks and reap the associated gains. For Islamic banks, increases in risk are supported by higher efficiency and higher capitalisation. This result highlights that efficiency is not panacea; as such it should be interesting for regulators who may want to tailor capitalisation requirements in line with bank efficiency level and bank type. Efficiency should not be used as the sole determinant for capital requirements particularly in countries where different bank types co-exist, such as Islamic and conventional.

\subsection{Impact of bank specific, macroeconomic and market structure variables}

Of the remaining bank-specific control variables, size positively affects insolvency risk of both bank types, while it is inversely related to the capitalisation of either bank. In both cases the effect is significantly more pronounced for the Islamic banks. In particular, the marginal effects of size on 
insolvency risk are $\hat{\beta}_{\text {Size } \mid C B}=0.925$ and $\hat{\beta}_{\text {size } \mid I B}=7.572$, while for capitalisation they are $\hat{\beta}_{\text {size } \mid C B}=$ -0.308 and $\hat{\beta}_{\text {size } \mid I B}=-5.959$ for conventional and Islamic banks respectively. In addition, size is inversely related to cost efficiency $\hat{\beta}_{\text {size } \mid C B}=-0.481$ but for conventional banks only. Overall, it appears that a larger bank size encourages riskier behaviour through two ways; a direct and an indirect one. First, a larger bank is more likely to (over-)rely on the "too-big-to-fail" doctrine; hence assume higher risk on the assumption that it would be bailed out (Demirgüç-Kunt and Huizinga, 2010; Gorton and Huang, 2004; Tarashev et al., 2009). Indeed, several studies have found evidenced of increased risk with government participation for financial institutions (Berger et al., 2005; Cornett et al., 2010; Iannotta et al., 2007). This is clearly evidenced from the positive coefficient on $\hat{\beta}_{\text {Size }}$ for conventional and, in particular, Islamic banks. The pronounced effect for Islamic banks might be plausibly related to the prominence that these banks enjoy in some countries, and their ownership status and close connections with the government and/or royal families which corroborates with the view that decisions in government-owned banks may not be based on entirely economic criteria (Iannotta et al., 2007). Second, larger banks withhold less capital; the latter being inversely linked to bank risk taking as highlighted in an earlier section. This is particularly relevant for conventional banks who have unrestricted access to capital markets.

Real GDP growth reduces risk taking in conventional banks $\hat{\beta}_{G D P G R \mid C B}=-1.329$, while the opposite result is reached for Islamic banks $\hat{\beta}_{G D P G R \mid I B}=7.772$. The result for conventional banks is in line with our expectations and the literature that finds banks located in fast growing countries to have a relatively low portion of bad loans, hence lower risk (Angkinand and Wihlborg, 2010; Laeven and Levine, 2009). However, Islamic banks have most of their investments in real assets, which are directly affected by the macroeconomic conditions. It might be plausible that during periods of economic boom, Islamic banks increase their risk taking to exploit the good economic conditions and reap the extra returns. Both bank types exhibit an inverse relationship between real GDP growth and capitalisation suggesting that in good economic climate capitalisation levels tend to reduce as banks channel more funds into investments while limit their protective cushions. The effect is particularly pronounced and significant for Islamic banks $\hat{\beta}_{G D P G R \mid I B}=-7.593$, while for conventional banks it is not statistically significant. An inverse relationship between real GDP growth and cost efficiency for both bank types suggests that any improvements in managerial skills and effort might be postponed during good economic times; possibly as the attention is gravitated elsewhere. This finding appears to be typical of emerging markets during economic expansion phases (Maudos et al., 2002).

A positive relationship between inflation and capitalisation is evidenced for both bank types; however, the magnitude is around eight times more pronounced in Islamic banks. This is plausible given that Islamic banks are sensitive to inflationary pressure due to the specifics of the profit-and-loss sharing contracts that are utilised, which cannot be inflation-linked or have varying maturities (Pappas et al., 2017). This manifests into an important concern for the bank - which has to bear such risks entirely particularly when taking into account the volatile and/or high inflation rates in these countries but also the lack of specialized hedging instruments to the Islamic banks' disposal. A positive impact of inflation on insolvency risk is evidenced for conventional banks, whereas for Islamic banks the effect is negative. For Islamic banks it corroborates their inability to operate in unstable economic environments, as this is manifested through high inflationary rates. Conversely, for conventional banks this seems not to be a concern as they can hedge themselves against such risks either through capital markets or less restrictive products they offer (e.g., rates in line with inflation). 
Concentration increases (decreases) risk for conventional (Islamic) banks. By contrast, higher concentration in the banking industry decreases (increases) the capitalisation of conventional (Islamic) banks. The impact of concentration on efficiency is positive for both bank types. It appears that a more concentrated market is beneficial for Islamic banks, which perhaps enjoy a "quiet life" by being the dominant player. This is not surprising due to the infancy stage of Islamic banks and the fact that most of their products are still largely unstandardized and comprise a highly manual process.

\subsection{Robustness Check}

Our sample contains Iran, whose banking system is entirely Islamic. To check whether or results are biased due to the inclusion of Iran as Iran dominates the sample of Islamic banks, we re-examined the SUR models by excluding Iran from our data. With the exception of the cost efficiency's effect on both capital and Z-score in models II and Model III, the results derived from these estimations remain robust and consistent across the baseline estimations (See Table 5a).

[Table 5a around here]

To check whether our results are not driven by a potential simultaneity bias that could arise due to the potential endogeneity of the firm-specific variables, we make use of the Two Stage Least Squares analysis (G2SLS IV RE). For the three different models each using three equations to examine the relationship between the three parameters namely risk, capital and efficiency, different instrumental variables are used to examine the endogeneity bias. For the first model which examines the impact on risk, capitalization and efficiency are considered endogenous; for the second model which examines the impact on capitalization, risk and efficiency are considered endogenous and for the last model which examines the impact on cost efficiency, capitalization and risk are considered endogenous. With the exception of the behavior of a few variables in only two equations of Model I, the results derived from these estimations remain robust and consistent across alternative specification. ${ }^{11}$ The G2SLS IV-RE estimates show that for the overall sample large size leads to increased riskiness. However, for Islamic banks an increase in size results in less riskiness. Overall the robustness test suggests that the baseline results do not appear to be driven by endogeneity bias. ${ }^{12}$

\section{[Table $5 \mathrm{~b}$ around here]}

We also introduce times fixed effect in our baseline model in table $5 \mathrm{c}$. The difference between the baseline table $5 \mathrm{a}$ and $5 \mathrm{c}$ is minimal.

[Table 5c around here]

To assess the robustness of our results with respect to the risk measure applied, we have used a second measure of risk, LLP/TL, LLPTL is loan-loss reserves to total loans ratio, instead of Z-score. Table $5 \mathrm{~d}$ presents the results of the relationship between capital, efficiency and risk, where LLPTL is used as an alternative risk measure. Z-score is usually used as a proxy for insolvency risk and indicates the

\footnotetext{
${ }^{11}$ The Durbin-Wu-Hausman test is performed which checks the exogeneity of capitalization risk and efficiency in the three models; the null hypothesis that the three variables are exogenous fails to be rejected at $5 \%$ significance level, favouring the results from the SUR model. To decide between fixed-effects and random-effects model the Hausman test is employed, where the null hypothesis that the bank effects are uncorrelated with the additional variables is not rejected, favouring the randomeffects estimator. Therefore, the model is estimated using a random-effects instrumental approach. The results of the G2SLS analysis are presented in table $5 \mathrm{~b}$. With a few exceptions, the G2SLS IV-RE estimates do not differ from baseline results.
} 
distance from insolvency and combines accounting measures of leverage, profitability and volatility whereas LLPTL is used as a proxy for credit risks as it reflects on the quality of the loan portfolio, thus slight differences are expected to be seen between the results of table 4,5c and table 5d. When LLPTL is used as a proxy increase in capital and efficiency lead to an increase in risk showing that there is a trade-off between increasing capital and maintaining a high profit efficiency, however when z-score is use which is an indicator which takes into account leverage, profitability and volatility, the results are different and in line with that of Saeed et al. (2014) whereby there is no trade-off between efficiency and low risk. The effect of bank specific and macro level variables on risk, where LLPTL is used as a proxy for risk is observed to be the same regardless of the risk proxy used. Although just a few macro level variables have differing signs from our expected results as well as those observed when $\mathrm{Z}$-score is used as a proxy for risk.

[Table 5d around here]

\section{Conclusion}

Our paper investigates the triple-relationship between risk, capital and efficiency for Islamic and conventional banks. Our data span 14 countries over the 2000-2012 period and comprise 65 Islamic and 180 conventional banks. We use the z-score as a proxy for insolvency risk, and cost efficiency estimated via a stochastic frontier approach. Our capitalisation proxy is the equity to assets. An array of bankspecific, macroeconomic and market structure variables are used in a system of three equations, estimated using the seemingly unrelated regression (SUR) technique.

With regards to the three key variables our findings suggest that the capitalisation response to increases in insolvency risk is significantly more pronounced in the case of Islamic banks but has an approximately five-times smaller effect on risk taking compared to conventional banks. This markedly different result for Islamic banks is driven in part by their reliance on investment account holders who are better suited to monitor the bank's activities compared to conventional depositors and the better capitalisation of Islamic banks. Thus, AAOFI and IFSB, the two regulatory bodies for Islamic banks, should take into consideration the need to revaluate the risk weighting of the required capital in accordance to Basel III regulations. In the long run, the likelihood of Islamic banks facing a trade-off between risk and capitalization can widen which can consequently affect the performance of IBs globally.

For both bank types a reduction in risk is beneficial for cost efficiency, albeit this effect is less pronounced for the Islamic banks. Conversely, increases in cost efficiency are perceived differently by the two bank types with regards to their risk levels. In particular, higher cost efficiency is related to lower risk for conventional banks, which offers an affirmation to the notion that more efficient banks could be granted with a softer regulatory touch. The opposite is verified for Islamic banks, as the most efficient of these institutions seem to bear the highest risk.

Higher cost efficiency is associated with lower capitalisation and vice versa for conventional banks, a result suggestive of a substitution effect between capitalisation and cost efficiency. However, the results for Islamic banks suggest that higher cost efficiency is associated with increased capitalisation; a complementary relationship. Hence, efficiency should be used with caution to gauge capital requirement levels particularly in countries where both bank types co-exist. This behaviour warrants interest from the AAOIFI and IFSB as well in that IBs attain higher cost efficiency due to higher capital requirements and as such if the rules are relaxed then the IBs might operate differently. Such reliance 
on increased capital requirements leading to cost efficiency can be a double-edged sword for Islamic banks. The focus of banks should be to facilitate banking intermediation and increase financial inclusion and thus achieve efficiencies so that Islamic banking industry can maintain stable growth in the long run.

Bank size positively affects insolvency risk of both bank types and is inversely related to the capitalisation of either bank; both effects are stronger in the case of Islamic banks. Real GDP growth reduces risk taking in conventional banks while the opposite result is reached for Islamic banks, which might be linked to the investments focus of Islamic banks being in the real economy. An inverse relationship between real GDP growth and capitalisation suggests that in good times capitalisation levels are reduced and banks channel more funds into investments. Capitalisation of Islamic banks is particularly affected by inflationary pressure, which is to be anticipated given the specifics of the profitand-loss sharing contracts that are utilised therein and cannot be inflation-linked or have varying maturities.

Our findings are particularly relevant for regulators and policy makers in countries where both bank types operate. However, these may be generalised to those regulatory bodies who have substantially different bank types under their jurisdictions as they highlight the role of banking model in how banking risk may be impacted by capitalisation and efficiency.

There are several limitations to our study. First, due to the scarcity of literature with regards to studies within the risk-efficiency- capital paradigm, it is difficult to derive or suggest how AAOFI and IFSB can make changes in their regulatory framework to impose and phase out and improvise upon the BASEL III regulations. Another limitation is pertaining to the characteristic of the Islamic banking model; the fact that depositors or investment account holders in Islamic banks are considered to be investors who participate in profit and loss might have a positive or a negative effect on Islamic bank stability and efficiency.

Future work could extend our research in various directions that could not be covered in this study. The first suggestion stems from one of the main findings of this study, it is observed that there is no tradeoff between capitalization and efficiency. This directs our attention to the fact that higher capital requirements indeed have a positive effect on the efficiency of IBs. What remains to be seen is if it is true for smaller sized banks as well. If increased capital requirements adversely affect the efficiency of small banks then regulators are posed with significant questions regarding the outcomes of adapting and implementing the Basel III framework for both Islamic and conventional banks in the regions where this study has been conducted.

Another important suggestion is to investigate the capital requirements considering the weightings given to the capital adequacy ratio. This could help us evaluate the efficacy of the BASEL III accord. 
Table 1. Breakdown of banks by country and type.

\begin{tabular}{lcccr}
\hline Country & Islamic & Conventional & Total & Islamic \% \\
\hline Bahrain & 12 & 5 & 17 & $70.59 \%$ \\
Bangladesh & 2 & 24 & 26 & $7.69 \%$ \\
Egypt & 2 & 19 & 21 & $9.52 \%$ \\
Indonesia & 1 & 31 & 32 & $3.13 \%$ \\
Iran & 12 & 0 & 12 & $100.00 \%$ \\
Jordan & 2 & 9 & 11 & $18.18 \%$ \\
Kuwait & 5 & 6 & 11 & $45.45 \%$ \\
Malaysia & 8 & 18 & 26 & $30.77 \%$ \\
Pakistan & 4 & 12 & 16 & $25.00 \%$ \\
Qatar & 3 & 5 & 8 & $37.50 \%$ \\
Saudi Arabia & 2 & 9 & 11 & $18.18 \%$ \\
Tunisia & 1 & 12 & 13 & $7.69 \%$ \\
Turkey & 3 & 15 & 18 & $16.67 \%$ \\
UAE & 8 & $\mathbf{1 8}$ & 23 & $34.78 \%$ \\
Total & $\mathbf{6 5}$ & $\mathbf{2 4 5}$ & $26.53 \%$ \\
\hline
\end{tabular}

Notes: The table reports the study sample distributions by country and bank type. The sample period covers the period 2000 - 2012. The cross-sectional subsamples reflect 65 IBs and 180 CBs operating in 14 countries. The column Islamic \% denotes the percentage of banks in each country that correspond to Islamic banks. Data Source: Bankscope. 
Table 2. Description of variables.

\begin{tabular}{|c|c|c|}
\hline \multicolumn{3}{|c|}{ Panel A: Cost Efficiency estimation } \\
\hline Variable & Acronym & Description \\
\hline \multicolumn{3}{|l|}{ Bank-specific variables } \\
\hline Total Cost & $\mathrm{C}$ & $\begin{array}{l}\text { Interest expense }+ \text { personnel expenses }+ \text { other } \\
\text { administration expenses }+ \text { other operating expenses }\end{array}$ \\
\hline Price of Physical Capital & $w_{1}$ & $\begin{array}{l}\text { Ratio of non-interest expenses (operating cost net of } \\
\text { personnel expenses) to total fixed asset }\end{array}$ \\
\hline Price of Labour & $w_{2}$ & Personnel expenses to total assets \\
\hline Price of Financial Capital & $w_{3}$ & Interest expenses to total assets \\
\hline Net Total Loans & $y_{1}$ & Total loans net of provision \\
\hline Other Earning Assets & $y_{2}$ & $\begin{array}{l}\text { Deposits \& short-term funding other interest bearing } \\
\text { liabilities+ other non-interest bearing liabilities }\end{array}$ \\
\hline \multicolumn{3}{|l|}{ Macroeconomic variables } \\
\hline Market Concentration & MCONC & Assets of three largest banks to total assets of the sector \\
\hline Degree of monetization & MONET & Broad money supply (M2) divided by GDP \\
\hline GDP per Capita & GDPPC & Ratio of GDP to total population \\
\hline GDP growth & GDPG & Year-on-year logarithmic change real GDP \\
\hline Market Capitalization \% & MKTGD & Market Capitalization of listed companies as a \% of \\
\hline GDP & $\mathrm{P}$ & GDP \\
\hline Annual inflation rate & INF & $\begin{array}{l}\text { Year-on-year logarithmic change on Consumer Price } \\
\text { Index }\end{array}$ \\
\hline Density of population & DPOP & Total inhabitant divided by area \\
\hline \multicolumn{3}{|c|}{ Panel B: Variables in SUR system of equations } \\
\hline Insolvency Risk & Z-score & (equity/assets $+R O A) / \sigma(R O A)$ \\
\hline Capitalisation & CAP & Equity to Total Assets \\
\hline Cost Efficiency & $\mathrm{CE}$ & Cost efficiency \\
\hline \multicolumn{3}{|l|}{ Bank-specific variables } \\
\hline Bank Size & SIZE & Natural logarithm of total assets \\
\hline Tax to pre-tax profit & TBPT & Ratio of tax to pre-tax profits \\
\hline Net Loans to total assets & NLTA & Ratio of net loans to total assets \\
\hline Profitability & ROA & Return on Assets \\
\hline Off-balance sheet activity & OBSTA & Ratio of off-balance-sheet items to total assets \\
\hline \multicolumn{3}{|l|}{ Market Structure variables } \\
\hline Concentration & MCONC & Concentration ratio of the three largest banks. \\
\hline \multicolumn{3}{|l|}{ Macroeconomic variables } \\
\hline Inflation & INF & $\begin{array}{l}\text { Year-on-year logarithmic change on Consumer Price } \\
\text { Index }\end{array}$ \\
\hline Real GDP growth & GDPG & Year-on-year logarithmic change on real GDP \\
\hline
\end{tabular}


Table 3. Descriptive statistics by bank type.

\begin{tabular}{|c|c|c|c|c|c|c|c|}
\hline \multirow[t]{2}{*}{ Variables } & & \multicolumn{2}{|c|}{ All banks } & \multicolumn{2}{|c|}{ Islamic banks } & \multicolumn{2}{|c|}{ Conventional banks } \\
\hline & & Mean & SD & Mean & SD & Mean & SD \\
\hline \multirow{6}{*}{ 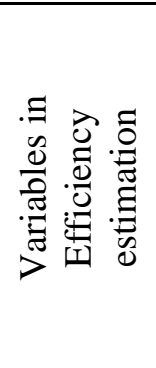 } & Total Cost & $6,050.30$ & $11,877.42$ & $5,934.47$ & $11,730.12$ & $6,083.56$ & $11,921.88$ \\
\hline & Price of Physical Capital $\left(w_{1}\right)$ & 3.552 & 32.328 & 10.370 & 67.613 & 1.590 & 4.127 \\
\hline & Price of Labour $\left(w_{2}\right)$ & 0.0124 & 0.0100 & 0.0126 & 0.0097 & 0.0123 & 0.0101 \\
\hline & Price of Financial Capital $\left(w_{3}\right)$ & 0.0365 & 0.0233 & 0.0297 & 0.0239 & 0.0385 & 0.0228 \\
\hline & Net Total Loans $\left(y_{1}\right)$ & $57,860.78$ & $95,920.92$ & $54,982.91$ & $90,709.41$ & $58,687.06$ & $97,370.38$ \\
\hline & Other Earning Assets $\left(y_{2}\right)$ & $1,224.93$ & $2,728.92$ & $1,643.56$ & $4,042.32$ & $1,104.74$ & $2,198.91$ \\
\hline \multirow{8}{*}{ 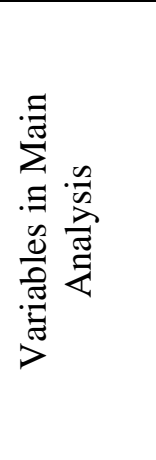 } & Z-score & 18.748 & 18.810 & $16.860^{* * * *}$ & $25.631^{* * * *}$ & 19.290 & 16.301 \\
\hline & Capitalisation & 0.1299 & 0.1156 & $0.1984^{* * *}$ & $0.2031^{* * *}$ & 0.1102 & 0.0602 \\
\hline & Cost efficiency & 0.8131 & 0.2061 & 0.7295 & $0.2683^{* * *}$ & 0.7331 & 0.1852 \\
\hline & Total Assets (SIZE) & $107,228.9$ & $172,346.8$ & $92,447.62^{* *}$ & $150,760.3^{* * * *}$ & $111,466.7$ & $177,867.3$ \\
\hline & ТРВТ & 0.2223 & 0.9837 & 0.2482 & $0.3015^{* * *}$ & 0.2148 & 1.1051 \\
\hline & ROA & 0.0154 & 0.0415 & 0.0132 & $0.0583^{* * *}$ & 0.0161 & 0.0352 \\
\hline & NLTA & 0.4462 & 0.2591 & $0.1499^{* * *}$ & $0.3048^{* * *}$ & 0.5311 & 0.1654 \\
\hline & OBSTA & 0.4563 & 3.0344 & $0.1902^{* *}$ & $2.387^{* * * *}$ & 0.5160 & 3.4366 \\
\hline
\end{tabular}

Notes: ${ }^{* * *},{ }^{* *},{ }^{*}$ denote statistical significance at the 1,5 and $10 \%$ significance level respectively for the unconditional tests of equality between the means (t-test) and variances (Levene's test) of Islamic versus conventional banks. 
Table 4. SUR regression estimates with Z-Score as a proxy for Risk

\begin{tabular}{|c|c|c|c|c|c|c|c|c|c|c|}
\hline & Equation & & 1 & & & 2 & & & 3 & \\
\hline & Model & I & II & III & I & II & III & I & II & III \\
\hline & & Z-score (I & solvency ris & & & Capital & & & ost Efficien & \\
\hline & Z-score & - & - & - & $0.647^{* * * *}$ & $0.620^{* * * *}$ & $0.574^{* * *}$ & $0.335^{* * *}$ & $0.265^{* * *}$ & $0.350^{* * * *}$ \\
\hline & & & & & $(0.000)$ & $(0.000)$ & $(0.000)$ & $(0.000)$ & $(0.000)$ & $(0.000)$ \\
\hline & Capital & $18.808^{* * *}$ & $41.867^{* * *}$ & $49.214^{* * *}$ & - & - & - & $-16.386^{* * *}$ & $-33.491^{* * * *}$ & $-39.748^{* * * *}$ \\
\hline & & $(0.040)$ & $(0.170)$ & $(0.170)$ & & & & $(0.040)$ & $(0.160)$ & $(0.170)$ \\
\hline & Efficiency & $1.722^{* * *}$ & $7.862^{* * *}$ & $5.214^{* * * *}$ & $-2.232^{* * *}$ & $-7.190^{* * * *}$ & $-6.498^{* * *}$ & - & - & - \\
\hline & & $(0.020)$ & $(0.080)$ & $(0.080)$ & $(0.030)$ & $(0.070)$ & $(0.070)$ & & & \\
\hline 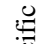 & Size & $1.314^{* * *}$ & $1.015^{* * *}$ & $0.925^{* * *}$ & $-0.825^{* * *}$ & $-0.639^{* * * *}$ & $-0.308^{* * *}$ & $-0.464^{* * * *}$ & $-0.152^{* * *}$ & $-0.481^{* * *}$ \\
\hline ֻ & & $(0.000)$ & $(0.010)$ & $(0.010)$ & $(0.000)$ & (0.010) & $(0.010)$ & $(0.000)$ & $(0.010)$ & $(0.010)$ \\
\hline 立 & TPBT & $-0.267^{* * *}$ & $-0.206^{* * *}$ & $-0.210^{* * *}$ & $0.197^{\text {*** }}$ & $0.182^{* * *}$ & $0.210^{* * *}$ & $0.116^{* * * *}$ & $0.048^{* * *}$ & $0.095^{* * *}$ \\
\hline जี & & $(0.000)$ & $(0.010)$ & $(0.010)$ & $(0.000)$ & $(0.010)$ & $(0.010)$ & $(0.000)$ & $(0.000)$ & $(0.000)$ \\
\hline & NLTA & $1.266^{* * *}$ & $1.106^{* * *}$ & $3.170^{* * * *}$ & & & & & & \\
\hline & & $(0.010)$ & $(0.030)$ & $(0.060)$ & & & & & & \\
\hline & ROA & & & & $-3.455^{* * *}$ & $-6.889^{* * *}$ & $-14.168^{* * * *}$ & & & \\
\hline & & & & & $(0.060)$ & $(0.120)$ & $(0.160)$ & & & \\
\hline & OBSTA & & & & & & & $0.019^{* * *}$ & $-0.008^{* * * *}$ & 0.000 \\
\hline & & & & & & & & $(0.000)$ & $0.000)$ & $(0.000)$ \\
\hline & MCONC & $2.983^{* * *}$ & $3.567^{* * *}$ & $2.629^{* * * *}$ & $-3.362^{* * *}$ & $-3.604^{* * * *}$ & $-4.355^{* * *}$ & $1.218^{* * *}$ & $-0.317^{* * *}$ & $1.789^{* * *}$ \\
\hline $\bar{\Xi}$ & & $(0.040)$ & $(0.100)$ & $(0.110)$ & $(0.040)$ & $(0.100)$ & (0.100) & $(0.040)$ & $(0.070)$ & $(0.080)$ \\
\hline हี & GDPGR & $2.879^{* * *}$ & $5.060^{* * *}$ & $-1.329^{* * *}$ & $-5.691^{* * *}$ & $-4.909^{* * *}$ & $-0.756^{*}$ & $0.896^{* * *}$ & $-0.655^{* * *}$ & $-0.699^{* *}$ \\
\hline อ & & $(0.140)$ & $(0.400)$ & $(0.390)$ & $(0.150)$ & $(0.360)$ & $(0.370)$ & $(0.100)$ & $(0.190)$ & $(0.220)$ \\
\hline$\stackrel{\tilde{z}}{\Sigma}$ & INF & $-0.790^{* * *}$ & $-1.327^{* * *}$ & $0.650^{* * *}$ & $0.930^{* * *}$ & $0.926^{* * *}$ & $0.432^{* * *}$ & $-1.345^{* * *}$ & $-2.079^{* * *}$ & $-3.074^{* * *}$ \\
\hline & & $(0.040)$ & $(0.110)$ & $(0.120)$ & $(0.040)$ & $(0.100)$ & $(0.110)$ & $(0.030)$ & $(0.050)$ & $(0.070)$ \\
\hline & IB $x$ Z-score & - & - & - & - & $0.051^{* * *}$ & $0.182^{* * *}$ & - & $-0.022^{* * * *}$ & $-0.172^{* * *}$ \\
\hline & & & & & & $(0.000)$ & $(0.000)$ & & $(0.000)$ & $(0.000)$ \\
\hline & IB x Capital & - & $-34.117^{* * *}$ & $-39.463^{* * * *}$ & - & 一 & 一 & 一 & $27.632^{* * *}$ & $32.606^{* * *}$ \\
\hline & & & $(0.190)$ & $(0.200)$ & & & & & $(0.190)$ & $(0.200)$ \\
\hline & IB x Efficiency & - & $-16.848^{* * * *}$ & $-15.001^{* * *}$ & - & $14.583^{* * *}$ & $14.707^{* * *}$ & - & - & - \\
\hline & & & $(0.160)$ & $(0.140)$ & & $(0.140)$ & $(0.130)$ & & & \\
\hline & IB $x$ Size & - & - & $6.647^{* * * *}$ & - & 一 & $-5.651^{* * *}$ & 一 & - & $0.417^{* * * *}$ \\
\hline & & & & $(0.120)$ & & & $(0.110)$ & & & $(0.080)$ \\
\hline & IB $x$ TPBT & - & - & $-1.370^{* * *}$ & - & - & -0.079 & - & - & $0.450^{* * * *}$ \\
\hline .0 & & & & $(0.080)$ & & & $(0.070)$ & & & $(0.050)$ \\
\hline$\stackrel{\pi}{ \pm}$ & IB x NLTA & - & - & $-2.214^{* * *}$ & - & - & - & - & - & \\
\hline.$\Xi$ & & & & $(0.070)$ & & & & & & \\
\hline 范 & IB x ROA & - & - & - & - & - & $10.796^{\text {*** }}$ & - & - & \\
\hline$\vec{e}$ & & & & & & & $(0.240)$ & & & \\
\hline ప్ & IB x OBSTA & - & 一 & - & - & - & - & - & - & $-0.069^{* * *}$ \\
\hline$\approx$ & & & & & & & & & & $(0.000)$ \\
\hline & IB x MCONC & - & - & $-3.393^{* * *}$ & - & - & $3.069^{* * *}$ & 一 & - & $0.609^{* * *}$ \\
\hline & & & & $(0.220)$ & & & $(0.200)$ & & & $(0.170)$ \\
\hline & IB x GDPGR & - & - & $9.101^{* * *}$ & - & - & $-6.837^{* * *}$ & - & - & 0.120 \\
\hline & & & & $(0.840)$ & & & $(0.800)$ & & & $(0.470)$ \\
\hline & IB $x$ INF & - & - & $-5.800^{* * *}$ & - & 一 & $3.474^{* * * *}$ & - & - & $4.279^{* * * *}$ \\
\hline & & & & $(0.210)$ & & & $(0.200)$ & & & $(0.120)$ \\
\hline & IB & $4.205^{* * *}$ & $18.177^{* * *}$ & $13.891^{* * *}$ & $-4.472^{* * *}$ & $-13.600^{* * * *}$ & $-11.491^{* * * *}$ & $1.163^{* * * *}$ & $-1.092^{* * * *}$ & $-0.449^{* *}$ \\
\hline & & $(0.040)$ & $(0.120)$ & $(0.210)$ & $(0.030)$ & $(0.120)$ & $(0.180)$ & $(0.050)$ & $(0.100)$ & $(0.160)$ \\
\hline & Observations & 2736 & 2736 & 2736 & 2736 & 2736 & 2736 & 2736 & 2736 & 2736 \\
\hline & Sample period & $2000-12$ & $2000-12$ & $2000-12$ & $2000-12$ & $2000-12$ & $2000-12$ & $2000-12$ & $2000-12$ & $2000-12$ \\
\hline
\end{tabular}

Notes: The table reports estimated coefficients and robust standard errors in parenthesis from the SUR estimation of the system of equations in section 3. Insolvency risk is proxied by the z-score, capital is proxied by the Equity to Assets ratio and Efficiency refers to cost efficiency derived from SFA (see section 3.1). Each equation is estimated as three models (labelled I, II and III) allowing for increasing distinctiveness between the two bank types. *** ,** * denote statistical significance at the 1,5 and $10 \%$ respectively. 


\begin{tabular}{|c|c|c|c|c|c|c|c|c|c|c|}
\hline \multirow{2}{*}{\multicolumn{2}{|c|}{$\begin{array}{ll}\text { Equation } \\
\text { Model }\end{array}$}} & \multicolumn{3}{|c|}{1} & \multicolumn{3}{|c|}{2} & \multicolumn{3}{|c|}{3} \\
\hline & & I & II & III & $\mathrm{I}$ & II & III & I & II & III \\
\hline & & \multicolumn{3}{|c|}{ Z-score (Insolvency risk) } & \multicolumn{3}{|c|}{ Capital } & \multicolumn{3}{|c|}{ Cost Efficiency } \\
\hline \multirow{16}{*}{ 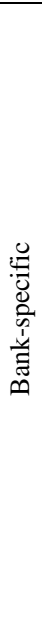 } & Z-score & - & - & - & $0.127^{* * *}$ & $-0.299^{* * * *}$ & $0.767^{* * * *}$ & $0.123^{* * *}$ & $-0.610^{* * * *}$ & $-0.187^{* * * *}$ \\
\hline & & & & & $(0.00)$ & $(0.00)$ & $(0.01)$ & $(0.00)$ & $(0.00)$ & $(0.00)$ \\
\hline & Capital & $50.734^{* * *}$ & $85.869^{* * *}$ & $80.864^{* * *}$ & - & - & - & $-40.003^{* * *}$ & $91.776^{* * *}$ & $41.516^{* * *}$ \\
\hline & & $(0.10)$ & $(0.11)$ & $(0.17)$ & & & & $(0.35)$ & $(0.69)$ & $(0.90)$ \\
\hline & Efficiency & $-4.328^{* * * *}$ & $-2.741^{* * * *}$ & $-4.155^{* * *}$ & -0.067 & 0.292 & $-15.542^{* * *}$ & - & - & - \\
\hline & & $(0.05)$ & $(0.04)$ & $(0.07)$ & $(0.03)$ & $(0.17)$ & $(0.31)$ & & & \\
\hline & Size & $1.601^{* * * *}$ & $0.343^{* * *}$ & $0.683^{* * *}$ & $-0.140^{* * * *}$ & $0.199^{* * *}$ & $-0.180^{* * *}$ & $-1.313^{* * * *}$ & $0.795^{\text {**** }}$ & $0.354^{* * * *}$ \\
\hline & & $(0.01)$ & $(0.00)$ & $(0.01)$ & $(0.00)$ & $(0.02)$ & $(0.04)$ & $(0.02)$ & $(0.02)$ & $(0.03)$ \\
\hline & TPBT & $-0.110^{* * * *}$ & $-0.070^{* * * *}$ & $-0.107^{* * * *}$ & $0.024^{* * *}$ & -0.006 & $0.445^{* * *}$ & $0.050^{* *}$ & $-1.042^{* * * *}$ & $-0.493^{* * * *}$ \\
\hline & & $(0.01)$ & $(0.00)$ & $(0.01)$ & $(0.00)$ & $(0.02)$ & $(0.04)$ & $(0.02)$ & $(0.02)$ & $(0.03)$ \\
\hline & NLTA & $14.459^{* * * *}$ & $5.217^{* * * *}$ & $10.091^{* * *}$ & - & - & - & - & - & - \\
\hline & & $(0.06)$ & $(0.04)$ & $(0.08)$ & & & & & & \\
\hline & ROA & - & - & - & $-3.008^{* * *}$ & -0.315 & $-97.537^{* * *}$ & - & - & - \\
\hline & & & & & $(0.12)$ & $(0.53)$ & $(1.22)$ & & & \\
\hline & OBSTA & - & - & - & - & - & - & $-0.376^{* * *}$ & $0.542^{* * *}$ & $0.340^{* * * *}$ \\
\hline & & & & & & & & $(0.01)$ & $(0.01)$ & $(0.01)$ \\
\hline \multirow{6}{*}{ 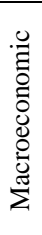 } & MCONC & $0.273^{* * *}$ & $9.061^{* * *}$ & $12.357^{* * * *}$ & $-2.193^{* * *}$ & $4.375^{* * *}$ & $-25.606^{* * *}$ & $17.668^{* * *}$ & $-19.436^{* * * *}$ & $-5.729^{* * * *}$ \\
\hline & & $(0.08)$ & $(0.05)$ & $(0.07)$ & $(0.05)$ & $(0.24)$ & $(0.50)$ & $(0.27)$ & $(0.30)$ & $(0.43)$ \\
\hline & GDPGR & $19.016^{* * *}$ & $1.037^{* * *}$ & $0.716^{* *}$ & $-0.944^{* * *}$ & $2.482^{* *}$ & $23.437^{\text {*** }}$ & $1.822^{*}$ & $14.691^{* * *}$ & $5.672^{* * *}$ \\
\hline & & $(0.22)$ & $(0.14)$ & $(0.25)$ & $(0.18)$ & $(0.82)$ & $(1.65)$ & $(0.76)$ & $(0.88)$ & (1.35) \\
\hline & INF & $-8.241^{* * * *}$ & $-1.192^{* * *}$ & $1.372^{* * *}$ & $1.207^{* * *}$ & $-1.512^{* * * *}$ & $12.560^{* * * *}$ & $-2.245^{* * *}$ & $-2.344^{* * * *}$ & -0.508 \\
\hline & & $(0.06)$ & $(0.04)$ & $(0.08)$ & $(0.05)$ & $(0.23)$ & $(0.49)$ & $(0.22)$ & $(0.25)$ & $(0.41)$ \\
\hline \multirow{25}{*}{ 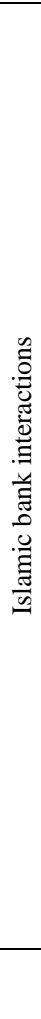 } & IB $x$ Z-score & - & - & - & - & $0.215^{\text {*** }}$ & $-0.877^{* * *}$ & - & $0.531^{* * *}$ & $0.113^{* * *}$ \\
\hline & & & & & & $(0.01)$ & $(0.01)$ & & $(0.01)$ & $(0.01)$ \\
\hline & IB x Capital & - & $-64.024^{* * *}$ & $-56.593^{* * *}$ & - & - & - & - & $-85.384^{* * *}$ & $-36.841^{* * *}$ \\
\hline & & & $(0.13)$ & $(0.21)$ & & & & & $(0.85)$ & (1.19) \\
\hline & IB $x$ Efficiency & - & $-27.227^{* * *}$ & $-22.517^{* * *}$ & - & $-5.232^{* * *}$ & $20.049^{* * * *}$ & - & - & - \\
\hline & & & $(0.09)$ & $(0.16)$ & & $(0.51)$ & $(0.92)$ & & & \\
\hline & IB x Size & - & - & $-1.344^{* * *}$ & - & - & $-0.418^{* * *}$ & - & - & $-0.240^{*}$ \\
\hline & & & & $(0.02)$ & & & $(0.11)$ & & & $(0.12)$ \\
\hline & IB $x$ TPBT & - & - & $7.303^{* * *}$ & - & - & $-6.439^{* * *}$ & - & - & -0.460 \\
\hline & & & & (0.09) & & & $(0.57)$ & & & $(0.46)$ \\
\hline & IB $x$ NLTA & - & - & $\begin{array}{l}-6.323^{* * *} \\
(0.12)\end{array}$ & - & - & - & - & - & \\
\hline & IB $x$ ROA & - & - & - & - & - & $104.715^{* * *}$ & - & - & \\
\hline & & & & & & & $(1.87)$ & & & \\
\hline & IB x OBSTA & - & - & - & - & - & - & - & - & $-0.913^{* *}$ \\
\hline & & & & & & & & & & $(0.34)$ \\
\hline & IB x MCONC & - & - & $-21.640^{* * *}$ & - & - & $11.720^{* * *}$ & - & - & $-9.316^{* * * *}$ \\
\hline & & & & $(0.19)$ & & & $(1.29)$ & & & (1.13) \\
\hline & IB x GDPGR & - & - & $19.150^{* * *}$ & - & - & $-22.013^{* * *}$ & - & - & 4.040 \\
\hline & & & & $(0.58)$ & & & $(3.85)$ & & & $(3.11)$ \\
\hline & IB $\mathrm{x}$ INF & - & - & $-11.730^{* * *}$ & - & - & $-14.001^{* * *}$ & - & - & -0.134 \\
\hline & & & & $(0.14)$ & & & $(0.93)$ & & & $(0.78)$ \\
\hline & IB & $25.841^{* * *}$ & $5.111^{* * *}$ & $29.153^{* * * *}$ & $1.881^{* * *}$ & $-9.977^{* * * *}$ & $14.135^{\text {*** }}$ & $2.183^{* * *}$ & $-13.892^{* * *}$ & $5.957^{* * *}$ \\
\hline & & $(0.05)$ & $(0.05)$ & $(0.25)$ & $(0.03)$ & $(0.30)$ & (1.54) & $(0.16)$ & $(0.23)$ & (1.54) \\
\hline & Observations & 2631 & 2631 & 2631 & 2631 & 2631 & 2631 & 2631 & 2631 & 2631 \\
\hline & Sample period & $2000-12$ & $2000-12$ & $2000-12$ & $2000-12$ & $2000-12$ & 2000-12 & $2000-12$ & $2000-12$ & $2000-12$ \\
\hline
\end{tabular}

Notes: The table reports estimated coefficients and robust standard errors in parenthesis from the SUR estimation of the system of equations in section 3. Insolvency risk is proxied by the z-score, capital is proxied by the Equity to Assets ratio and Efficiency refers to cost efficiency derived from SFA (see section 3.1). Each equation is estimated as three models (labelled I, II and III) allowing for increasing distinctiveness between the two bank types. ${ }^{* * *}{ }^{* *},{ }^{*}$ denote statistical significance at the 1,5 and $10 \%$ respectively. 
Table 5b. Robustness Test - G2SLS random effects IV regression. G2SLS (IV-RE)

\begin{tabular}{|c|c|c|c|c|c|c|c|c|c|c|}
\hline & Equation & & 1 & & & 2 & & & 3 & \\
\hline & Model & I & II & III & I & II & III & I & II & $\overline{\text { III }}$ \\
\hline & & Z-score (1) & olvency ris & & & Capital & & & Cost Efficier & \\
\hline \multirow{16}{*}{ 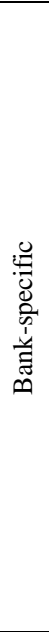 } & Z-score & - & - & - & 0.017 & 0.018 & 0.019 & $0.017 * *$ & $0.100 * * *$ & $0.118^{*}$ \\
\hline & & & & & $(0.03)$ & $(0.02)$ & $(0.03)$ & $(0.01)$ & $(0.03)$ & $(0.03)$ \\
\hline & Capital & $59.334^{*}$ & $43.743^{* *}$ & $48.777^{* *}$ & - & - & & $-3.620 * * *$ & $-7.257 * *$ & $-8.107 * * *$ \\
\hline & & (23.09) & (16.97) & (18.17) & & & & $(0.76)$ & $(2.44)$ & $(2.46)$ \\
\hline & Efficiency & 8.737 & 37.707 & 13.992 & -0.094 & -0.121 & -0.096 & - & & - \\
\hline & & (200.43) & (110.59) & (108.69) & $(0.23)$ & $(0.19)$ & $(0.22)$ & & & \\
\hline & Size & -0.656 & -1.875 & -0.965 & 0.002 & 0.003 & 0.010 & $-0.059 * * *$ & $-0.100 * *$ & $-0.079^{* *}$ \\
\hline & & $(6.97)$ & $(3.32)$ & $(0.78)$ & $(0.02)$ & $(0.02)$ & $(0.03)$ & $(0.01)$ & $(0.04)$ & $(0.03)$ \\
\hline & TPBT & $-0.273^{*}$ & $-0.316^{*}$ & -0.201 & 0.005 & 0.005 & 0.004 & 0.000 & 0.015 & 0.021 \\
\hline & & $(0.13)$ & $(0.14)$ & $(0.16)$ & $(0.01)$ & $(0.01)$ & $(0.01)$ & $(0.01)$ & $(0.01)$ & $-0.079^{* *}$ \\
\hline & NLTA & -0.884 & -8.969 & -5.456 & & & & & & \\
\hline & & (53.27) & (30.65) & (88.28) & & & & & & \\
\hline & ROA & & & & -0.011 & 0.053 & -0.056 & - & & \\
\hline & & & & & $(0.63)$ & $(0.32)$ & $(0.63)$ & - & & \\
\hline & OBSTA & & & & & & & 0.002 & 0.003 & 0.003 \\
\hline & & & & & & & & $(0.00)$ & $(0.00)$ & $(0.00)$ \\
\hline \multirow{6}{*}{ 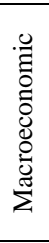 } & MCONC & 2.016 & 8.064 & 0.770 & -0.026 & 0.031 & 0.014 & -0.047 & $-0.484 * * *$ & $-0.635^{* * *}$ \\
\hline & & (50.53) & (34.60) & (26.22) & $(0.10)$ & $(0.04)$ & $(0.07)$ & $(0.10)$ & $(0.13)$ & $(0.13)$ \\
\hline & GDPGR & -1.479 & -11.587 & 2.193 & 0.031 & 0.064 & -0.073 & $0.722 *$ & -0.121 & -0.259 \\
\hline & & (38.48) & $(29.25)$ & $(26.81)$ & $(0.14)$ & $(0.07)$ & $(0.11)$ & $(0.30)$ & $(0.38)$ & $(0.42)$ \\
\hline & INF & 4.344 & 5.997 & 0.350 & -0.067 & -0.003 & 0.006 & $-0.390 * * *$ & 0.074 & 0.045 \\
\hline & & $(4.92)$ & (7.89) & (7.68) & $(0.15)$ & $(0.02)$ & $(0.02)$ & $(0.11)$ & $(0.12)$ & $(0.12)$ \\
\hline \multirow{25}{*}{ 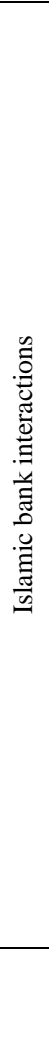 } & IB x Z-score & - & - & - & - & -0.015 & -0.015 & - & $-0.101 * * *$ & $-0.118^{* * *}$ \\
\hline & & & & & & $(0.02)$ & $(0.03)$ & & $(0.03)$ & $(0.03)$ \\
\hline & IB x Capital & - & $40.087^{* *}$ & $40.594^{*}$ & - & - & - & - & $7.513^{* *}$ & $8.175^{* * *}$ \\
\hline & & & (15.34) & (18.38) & & & & & $(2.45)$ & $(2.47)$ \\
\hline & IB $x$ Efficiency & - & -36.271 & -12.201 & - & 0.171 & -0.001 & - & - & - \\
\hline & & & (141.77) & (108.80) & & $(0.19)$ & $(0.23)$ & & & \\
\hline & IB x Size & - & - & -2.391 & - & - & -0.021 & - & - & 0.099 \\
\hline & & & & $(2.07)$ & & & $(0.04)$ & & & $(0.15)$ \\
\hline & IB $x$ TPBT & - & - & $-8.798^{* * *}$ & - & - & $0.091^{* * *}$ & - & - & -0.011 \\
\hline & & & & $(1.16)$ & & & $(0.01)$ & & & $(0.09)$ \\
\hline & IB x NLTA & - & - & $\begin{array}{c}3.442 \\
(88.28)\end{array}$ & - & - & - & - & - & \\
\hline & IB x ROA & - & - & - & - & - & $\begin{array}{l}0.186 \\
(0.64)\end{array}$ & - & - & \\
\hline & IB x OBSTA & - & - & - & - & - & - & - & - & -0.004 \\
\hline & & & & & & & & & & $(0.01)$ \\
\hline & IB x MCONC & - & - & -0.693 & - & - & $0.204^{*}$ & - & - & $1.054^{* * * *}$ \\
\hline & & & & (26.48) & & & $(0.08)$ & & & $(0.27)$ \\
\hline & IB x GDPGR & - & - & -24.828 & - & - & $0.321^{*}$ & - & - & 0.041 \\
\hline & & & & (27.94) & & & $(0.15)$ & & & $(0.77)$ \\
\hline & IB $x$ INF & - & - & 15.195 & - & - & -0.017 & - & - & 0.046 \\
\hline & & & & (8.04) & & & $(0.03)$ & & & $(0.22)$ \\
\hline & IB & -15.357 & -11.078 & -14.738 & 0.161 & 0.301 & 0.356 & $-0.224^{*}$ & 0.189 & $-0.449^{* *}$ \\
\hline & & (95.28) & (59.95) & (38.67) & $(0.29)$ & $(0.48)$ & $(1.74)$ & $(0.10)$ & $(0.29)$ & $(0.160)$ \\
\hline & Observations & 2736 & 2736 & 2736 & 2736 & 2736 & 2736 & 2736 & 2736 & 2736 \\
\hline & $\mathrm{R}^{2}$ & 0.0525 & 0.0358 & .0402 & .0674 & .0629 & .0658 & .0117 & .0058 & .0091 \\
\hline & Sample period & $2000-12$ & $2000-12$ & $2000-12$ & $2000-12$ & $2000-12$ & $2000-12$ & $2000-12$ & $2000-12$ & $2000-12$ \\
\hline
\end{tabular}

Notes: This table presents the results after using the Instrumental Variables (IV) approach to control for endogeneity. The table reports estimated coefficients and robust standard errors in parenthesis. Nine equations are estimated by the three models (labelled I, II and III) allowing for increasing distinctiveness between the two bank tvpes. ${ }^{* * *}{ }^{* *} .{ }^{*}$ denote statistical significance at the 1.5 and $10 \%$ respectivelv. 
Table 5c. Robustness Test - SUR regression estimates with year Fixed Effects

\begin{tabular}{|c|c|c|c|c|c|c|c|c|c|c|}
\hline \multirow{2}{*}{\multicolumn{2}{|c|}{$\begin{array}{ll}\text { Equation } \\
\text { Model } \\
\end{array}$}} & \multicolumn{3}{|c|}{1} & \multicolumn{3}{|c|}{2} & \multicolumn{3}{|c|}{3} \\
\hline & & I & II & III & I & II & III & I & $\mathrm{I}$ & III \\
\hline & & \multicolumn{3}{|c|}{ Z-score (Insolvency risk) } & \multicolumn{3}{|c|}{ Capital } & \multicolumn{3}{|c|}{ Cost Efficiency } \\
\hline \multirow{16}{*}{ 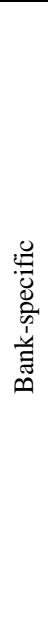 } & Z-score & - & - & - & & $0.025 * * *$ & $0.413^{* * *}$ & $16.931^{* * *}$ & $-45.006^{* * * *}$ & $-55.975^{* * *}$ \\
\hline & & & & & & $(0.00)$ & $(0.00)$ & $(0.12)$ & $(1.00)$ & $(0.25)$ \\
\hline & Capital & $17.632 * * *$ & $89.518^{* * * *}$ & $65.552^{* * *}$ & - & - & - & $-0.803^{* * *}$ & $0.231^{* * *}$ & $0.526^{* * *}$ \\
\hline & & $(0.10)$ & $(0.29)$ & $(0.23)$ & & & & $(0.00)$ & $(0.00)$ & $(0.00)$ \\
\hline & Efficiency & $-1.419 * * *$ & $4.470^{* * *}$ & $4.736^{* * *}$ & $1.012^{* * *}$ & $1.894 * * *$ & $-5.701^{* * *}$ & - & - & - \\
\hline & & $(0.05)$ & $(0.09)$ & $(0.10)$ & $(0.06)$ & $(0.13)$ & $(0.08)$ & & & \\
\hline & Size & $0.663 * * *$ & $1.058^{* * *}$ & $1.075^{* * *}$ & $0.052^{* * *}$ & - & $-0.113^{* * * *}$ & $0.545^{* * *}$ & 0.006 & $-0.917^{* * *}$ \\
\hline & & $(0.01)$ & $(0.01)$ & $(0.01)$ & $(0.01)$ & $(0.01)$ & $(0.01)$ & $(0.02)$ & $(0.04)$ & $(0.01)$ \\
\hline & TPBT & $-0.258 * * *$ & $-0.092^{* * *}$ & $-0.159^{* * *}$ & $-0.160^{* * *}$ & -0.028 & $0.153^{* * *}$ & $-0.317^{* * *}$ & $0.433^{* * *}$ & $0.135^{* * *}$ \\
\hline & & $(0.01)$ & $(0.01)$ & $(0.01)$ & $(0.01)$ & $(0.02)$ & $(0.01)$ & $(0.01)$ & $(0.03)$ & $(0.01)$ \\
\hline & NLTA & $2.573 * * *$ & $5.251^{* * *}$ & $2.733^{* * * *}$ & - & - & - & & & \\
\hline & & $(0.04)$ & $(0.07)$ & $(0.09)$ & & & & & & \\
\hline & ROA & & & & $1.880^{* * *}$ & $1.896 * * *$ & $-16.581^{* * *}$ & - & - & - \\
\hline & & & & & $(0.22)$ & $(0.50)$ & $(0.24)$ & & & \\
\hline & OBSTA & & & & & & & $0.041^{* * *}$ & $-0.283^{* * *}$ & $-0.006^{*}$ \\
\hline & & & & & & & & $(0.00)$ & $(0.01)$ & $(0.00)$ \\
\hline \multirow{6}{*}{ 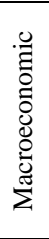 } & MCONC & $2.740^{* * *}$ & $-2.224^{* * *}$ & $1.489^{* * * *}$ & $3.712^{* * *}$ & $1.904 * * *$ & $-4.452^{* * *}$ & $-0.555^{* * *}$ & $1.095^{*}$ & $3.653^{* * *}$ \\
\hline & & $(0.11)$ & $(0.14)$ & $(0.14)$ & $(0.13)$ & $(0.18)$ & $(0.13)$ & $(0.15)$ & $(0.47)$ & $(0.15)$ \\
\hline & GDPGR & $1.159^{* * *}$ & $22.816^{* * *}$ & $-3.127^{* * * *}$ & $-3.238^{* * *}$ & 1.411 & $-1.931^{* * * *}$ & $1.250^{* * *}$ & -1.911 & $-1.824^{* * * *}$ \\
\hline & & $(0.30)$ & $(0.45)$ & $(0.47)$ & $(0.40)$ & $(0.85)$ & $(0.48)$ & $(0.38)$ & $(1.44)$ & $(0.37)$ \\
\hline & INF & $-1.060^{* * *}$ & $-1.594^{* * *}$ & $0.811^{* * *}$ & $-0.359^{* * *}$ & $-0.502 *$ & 0.083 & $1.548^{* * *}$ & 0.579 & $-4.359^{* * *}$ \\
\hline & & $(0.08)$ & $(0.12)$ & $(0.14)$ & $(0.10)$ & $(0.23)$ & $(0.14)$ & $(0.10)$ & $(0.37)$ & $(0.11)$ \\
\hline \multirow{26}{*}{ 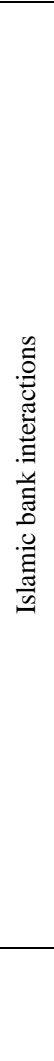 } & IB $x$ Z-score & - & - & - & - & $0.033 * * *$ & $0.248^{* * *}$ & & $-0.235^{* * *}$ & $-0.241^{* * * *}$ \\
\hline & & & & & & $(0.00)$ & $(0.00)$ & & $(0.01)$ & $(0.00)$ \\
\hline & IB x Capital & - & $-86.319^{* * * *}$ & $-55.350^{* * * *}$ & - & - & - & - & $44.130^{* * *}$ & $47.862^{* * *}$ \\
\hline & & & $(0.34)$ & $(0.27)$ & & & & & $(1.17)$ & $(0.29)$ \\
\hline & IB $x$ Efficiency & - & $-16.577^{* * *}$ & $-12.398^{* * *}$ & - & $-3.058^{* * *}$ & $12.204^{* * *}$ & - & - & - \\
\hline & & & $(0.16)$ & $(0.16)$ & & $(0.23)$ & $(0.15)$ & & & \\
\hline & IB x Size & - & - & $6.420^{* * *}$ & - & - & $-4.197^{* * * *}$ & - & - & $-0.621^{* * * *}$ \\
\hline & & & & $(0.13)$ & & & $(0.13)$ & & & $(0.12)$ \\
\hline & IB $x$ TPBT & - & - & $-1.938^{* * * *}$ & - & - & 0.093 & - & - & $1.124^{* * *}$ \\
\hline & & & & $(0.09)$ & & & $(0.09)$ & & & $(0.07)$ \\
\hline & IB x NLTA & - & - & $-1.760^{* * *}$ & - & - & - & - & - & - \\
\hline & & & & $(0.10)$ & & & & & & \\
\hline & IB x ROA & - & - & - & - & - & $\begin{array}{l}12.814^{* * *} \\
(0.37)\end{array}$ & - & - & - \\
\hline & IB x OBSTA & - & - & - & - & - & - & - & - & $-0.104^{* * * *}$ \\
\hline & & & & & & & & & & $(0.01)$ \\
\hline & IB x MCONC & - & - & $1.158^{* * * *}$ & - & - & $0.615^{* *}$ & - & - & -0.035 \\
\hline & & & & $(0.26)$ & & & $(0.24)$ & & & $(0.26)$ \\
\hline & IB x GDPGR & - & - & $5.757^{* * *}$ & - & - & $-5.596^{* * *}$ & - & - & $2.672^{* * *}$ \\
\hline & & & & $(0.93)$ & & & $(0.95)$ & & & $(0.73)$ \\
\hline & IB $x$ INF & - & - & $-4.789^{* * *}$ & - & - & $2.060^{* * *}$ & - & - & $5.855^{* * *}$ \\
\hline & & & & $(0.23)$ & & & $(0.23)$ & & & $(0.18)$ \\
\hline & IB & $-1.236^{* * *}$ & $25.368^{* * * *}$ & $13.777^{* * *}$ & $-5.146^{* * *}$ & 0.324 & $-10.277^{* * *}$ & $-2.416^{* * *}$ & $3.136^{* * *}$ & $-3.597^{* * *}$ \\
\hline & & $(0.11)$ & $(0.16)$ & $(0.25)$ & $(0.14)$ & $(0.20)$ & $(0.23)$ & $(0.16)$ & $(0.45)$ & $(0.24)$ \\
\hline & Observations & 2736 & 2736 & 2736 & 2736 & 2736 & 2736 & 2736 & 2736 & 2736 \\
\hline & Years Fixed & Yes & Yes & Yes & Yes & Yes & Yes & Yes & Yes & Yes \\
\hline & Sample period & $2000-12$ & $2000-12$ & $2000-12$ & $2000-12$ & $2000-$ & $2000-12$ & $2000-12$ & $2000-12$ & $2000-12$ \\
\hline
\end{tabular}

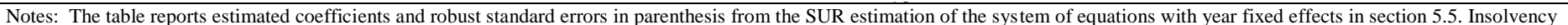

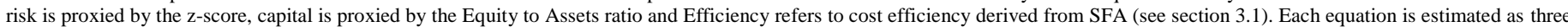
models (labelled I, II and III) allowing for increasing distinctiveness between the two bank types. ${ }^{* * *},{ }^{* *},{ }^{*}$ denote statistical significance at the 1,5 and $10 \%$ respectively. . 
Table 5d. Robustness Test - SUR regression estimates with year Fixed Effects and LLP/TL as a proxy for risk

\begin{tabular}{|c|c|c|c|c|c|c|c|c|c|c|}
\hline \multirow{2}{*}{\multicolumn{2}{|c|}{$\begin{array}{ll}\text { Equation } \\
\text { Model }\end{array}$}} & \multicolumn{3}{|c|}{1} & \multicolumn{3}{|c|}{2} & \multicolumn{3}{|c|}{3} \\
\hline & & $\mathrm{I}$ & II & III & I & II & III & I & II & III \\
\hline & & \multicolumn{3}{|c|}{ LLP/TL (Insolvency risk) } & \multicolumn{3}{|c|}{ Capital } & \multicolumn{3}{|c|}{ Cost Efficiency } \\
\hline \multirow{16}{*}{ 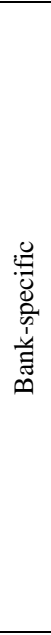 } & LLP/TL & - & - & - & $0.853^{* * *}$ & $-0.637^{* * * *}$ & $-1.623^{* * *}$ & $0.174^{* * *}$ & $-0.716^{* * *}$ & $0.554^{* * *}$ \\
\hline & & & & & $(0.00)$ & $(0.01)$ & $(0.01)$ & $(0.00)$ & $(0.01)$ & $(0.01)$ \\
\hline & Capital & $-0.764^{* * *}$ & $-0.040^{*}$ & $-0.203^{* * *}$ & - & - & - & $1.577^{* * *}$ & $0.812^{* * *}$ & 0.046 \\
\hline & & $(0.01)$ & $(0.02)$ & $(0.02)$ & & & & $(0.01)$ & $(0.04)$ & $(0.03)$ \\
\hline & Efficiency & $-0.800^{* * *}$ & $-0.059^{* * *}$ & $-0.618^{* * * *}$ & $1.632^{* * *}$ & $0.065^{* * *}$ & $-0.665^{* * *}$ & - & - & - \\
\hline & & (0.01) & (0.01) & $(0.01)$ & $-0.064^{* * *}$ & $0.008^{* * * *}$ & & & & $0003^{*}$ \\
\hline & Size & $0.037^{* * * 4}$ & $-0.022^{w a n}$ & $-0.028^{* * * *}$ & $-0.064^{\cdots}$ & $0.008^{\ldots \ldots}$ & -0.014 & 0.020 & 0.036 & -0.003 \\
\hline & & $(0.00)$ & $(0.00)$ & $(0.00)$ & $(0.00)$ & $(0.00)$ & $(0.00)$ & $(0.00)$ & $(0.00)$ & $(0.00)$ \\
\hline & TPBT & $-0.007^{* * *}$ & $0.003^{* * *}$ & $-0.001^{*}$ & $0.007^{* * *}$ & 0.003 & $-0.007^{* * *}$ & $0.009^{* * *}$ & $0.020^{* * *}$ & $-0.008^{* * *}$ \\
\hline & & $(0.00)$ & $(0.00)$ & $(0.00)$ & $(0.00)$ & $(0.00)$ & $(0.00)$ & $(0.00)$ & $(0.00)$ & $(0.00)$ \\
\hline & NLTA & $0.171^{* * *}$ & $0.040^{* * *}$ & $0.136^{* * *}$ & - & - & - & - & - & - \\
\hline & & $(0.00)$ & $(0.00)$ & $(0.01)$ & & & & & & \\
\hline & ROA & - & - & - & $0.298^{* * *}$ & 0.068 & $0.268^{* * *}$ & - & - & - \\
\hline & & & & & $(0.01)$ & $(0.05)$ & $(0.05)$ & & & \\
\hline & OBSTA & - & - & - & - & - & - & $0.000^{*}$ & $0.005^{* * *}$ & $-0.002^{* * * *}$ \\
\hline & & & & & & & & $(0.00)$ & $(0.00)$ & $(0.00)$ \\
\hline \multirow{6}{*}{ 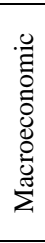 } & MCONC & 0.011 & $0.327^{* * *}$ & $0.702^{* * *}$ & $0.129^{* * *}$ & $-0.044^{*}$ & $0.689^{* * *}$ & $-0.058^{* * *}$ & $0.066^{* *}$ & $0.478^{* * * *}$ \\
\hline & & $(0.01)$ & $(0.01)$ & $(0.01)$ & $(0.01)$ & $(0.02)$ & $(0.02)$ & $(0.01)$ & $(0.02)$ & $(0.02)$ \\
\hline & GDPGR & $0.159^{* * *}$ & -0.048 & $0.329^{* * *}$ & -0.016 & $0.331^{* * *}$ & $0.535^{* * *}$ & $-0.100^{* * *}$ & $-0.864^{* * *}$ & $1.219^{* * *}$ \\
\hline & & $(0.04)$ & $(0.03)$ & $(0.03)$ & $(0.05)$ & $(0.08)$ & $(0.09)$ & $(0.02)$ & $(0.07)$ & $(0.06)$ \\
\hline & INF & -0.011 & $-0.063^{* * *}$ & 0.014 & $-0.103^{* * *}$ & -0.019 & $0.094^{* * *}$ & 0.002 & $-0.183^{* * *}$ & $-0.033^{*}$ \\
\hline & & $(0.01)$ & $(0.01)$ & $(0.01)$ & $(0.01)$ & $(0.02)$ & $(0.03)$ & $(0.01)$ & $(0.02)$ & $(0.02)$ \\
\hline \multirow{23}{*}{ 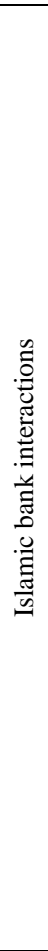 } & IB $x$ LLP/TL & - & - & - & - & $0.481^{* * *}$ & $0.781^{* * * *}$ & - & $1.034^{* * *}$ & $-1.455^{* * *}$ \\
\hline & & & & & & $(0.01)$ & $(0.01)$ & & $(0.01)$ & $(0.01)$ \\
\hline & IB x Capital & - & $-3.887^{* * * *}$ & $-2.667^{* * *}$ & - & - & 一 & - & $0.883^{* * * *}$ & $-2.281^{\text {**** }}$ \\
\hline & & & $(0.02)$ & $(0.02)$ & & & & & $(0.05)$ & $(0.04)$ \\
\hline & IB $x$ Efficiency & - & $-1.270^{* * *}$ & $-0.663^{* * *}$ & - & 0.019 & $-0.675^{* * *}$ & - & - & - \\
\hline & & & $(0.01)$ & $(0.01)$ & & $(0.02)$ & $(0.02)$ & & & \\
\hline & IB x Size & - & - & $1.203^{* * *}$ & - & - & $1.389^{* * *}$ & 一 & - & $1.134^{* * *}$ \\
\hline & & & & $(0.01)$ & & & $(0.02)$ & & & $(0.02)$ \\
\hline & IB $x$ TPBT & - & - & $-0.094^{* * *}$ & - & - & $-0.388^{* * *}$ & 一 & - & $-0.332^{* * *}$ \\
\hline & & & & $(0.01)$ & & & $(0.02)$ & & & $(0.01)$ \\
\hline & IB $\times$ NLTA & - & - & $\begin{array}{c}-0.146^{* * *} \\
(0.01)\end{array}$ & - & - & - & - & - & - \\
\hline & IB $x$ ROA & - & - & - & - & - & 0.113 & - & - & - \\
\hline & & & & & & & $(0.08)$ & & & \\
\hline & IB $\times$ OBSTA & - & - & - & - & - & - & - & - & $0.019^{* * *}$ \\
\hline & & & & & & & & & & $(0.00)$ \\
\hline & IB $x$ MCONC & - & - & 0.032 & - & - & -0.022 & - & - & $0.668^{* * *}$ \\
\hline & & & & $(0.02)$ & & & $(0.04)$ & & & $(0.03)$ \\
\hline & IB x GDPGR & - & - & $0.756^{* * *}$ & - & - & -0.318 & - & - & $-0.417^{* * *}$ \\
\hline & & & & $(0.07)$ & & & $(0.18)$ & & & $(0.11)$ \\
\hline & IB $x$ INF & - & - & $-0.167^{* * * *}$ & 一 & - & $-0.256^{* * *}$ & - & - & $-0.465^{* * *}$ \\
\hline & & & & $(0.02)$ & & & $(0.04)$ & & & $(0.03)$ \\
\hline & IB & $10.449^{* * *}$ & $11.683^{* * *}$ & $10.246^{* * *}$ & $-9.158^{* * *}$ & $1.704^{* * *}$ & $8.312^{* * *}$ & $-1.507^{* * *}$ & $-2.974^{* * *}$ & $8.558^{* * *}$ \\
\hline & & $(0.01)$ & $(0.01)$ & $(0.02)$ & $(0.02)$ & $(0.04)$ & $(0.05)$ & $(0.02)$ & $(0.05)$ & $(0.04)$ \\
\hline & Observations & 2736 & 2736 & 2736 & 2736 & 2736 & 2736 & 2736 & 2736 & 2736 \\
\hline & Years Fixed & Yes & Yes & Yes & Yes & Yes & Yes & Yes & Yes & Yes \\
\hline & Sample period & $2000-12$ & $2000-12$ & $2000-12$ & $2000-12$ & $2000-12$ & $2000-12$ & $2000-12$ & 2000-12 & 2000-12 \\
\hline
\end{tabular}

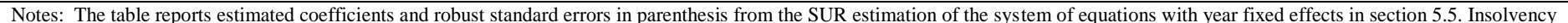

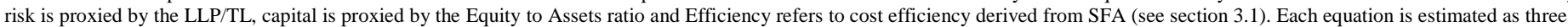
models (labelled I, II and III) allowing for increasing distinctiveness between the two bank types. ${ }^{* * *},{ }^{* *},{ }^{*}$ denote statistical significance at the 1,5 and $10 \%$ respectively. . 


\section{References}

Abdul-Majid, M., Nor, N.G.M., Said, F.F., 2005. Efficiency of Islamic banks in Malaysia. Islam. Financ. Econ. Dev.

Abdul-Majid, M., Saal, D.S., Battisti, G., 2010. Efficiency in Islamic and conventional banking: an international comparison. J. Product. Anal. 34, 25-43. doi:10.1007/s11123-009-0165-3

Abedifar, P., Ebrahim, S.M., Molyneux, P., Tarazi, A., 2015. Islamic Banking and Finance: Recent Empirical Literature and Directions for Future Research. J. Econ. Surv. 29, 637-670. doi:10.1111/joes.12113

Abedifar, P., Hasan, I., Tarazi, A., 2016. Finance-growth nexus and dual-banking systems: Relative importance of Islamic banks. J. Econ. Behav. Organ. 132, 198-215. doi:10.1016/j.jebo.2016.03.005

Abedifar, P., Molyneux, P., Tarazi, A., 2013. Risk in islamic banking. Rev. Financ. 17, 2035-2096. doi:10.1093/rof/rfs041

Akhtar, S., Akhtar, F., Jahromi, M., John, K., 2017. Intensity of volatility linkages in Islamic and conventional markets, in: KFUPM Islamic Banking and Finance Research Conference 2017.

Al-Jarrah, I., Molyneux, P., 2006. Cost Efficiency, Scale Elasticity and Scale Economies in Arab Banking. Banks Bank Syst. 1, 60-89.

Al-Muharrami, S., 2008. An examination of technical, pure technical and scale efficiencies in GCC banking. Am. J. Financ. Account. 1, 152-166.

Alexakis, C., Al-Yahyaee, K., Mamatzakis, E., Mobarek, A., Mollah, S., Pappas, V., 2017. Does corporate governance add value to Islamic banks? A cost efficiency and financial stability approach. Work. Pap.

Alhomaidi, A., Kabir Hassan, M., 2017. The effect of implicit market barriers on stock trading and liquidity, in: KFUPM Islamic Banking and Finance Research Conference 2017.

Altunbas, Y., Carbo, S., Gardener, E.P.M., Molyneux, P., 2007. Examining the Relationships between Capital, Risk and Efficiency in European Banking 13, 49-70.

Alzahrani, M., Megginson, W.L., 2017. Finance as worship: A survey of Islamic finance research. SSRN eLibrary.

Angelini, P., Clerc, L., Cúrdia, V., Gambacorta, L., Gerali, A., Locarno, A., Motto, R., Roeger, W., Van den Heuvel, S., Vlček, J., 2015. Basel III: Long-term Impact on Economic Performance and Fluctuations. Manchester Sch. 83, 217-251. doi:10.1111/manc.12056

Angkinand, A., Wihlborg, C., 2010. Deposit insurance coverage, ownership, and banks' risk-taking in emerging markets. J. Int. Money Financ. 29, 252-274. doi:https://doi.org/10.1016/j.jimonfin.2009.08.001

Ariss, R.T., 2010. Competitive conditions in Islamic and conventional banking: A global perspective. Rev. Financ. Econ. 19, 101-108. doi:https://doi.org/10.1016/j.rfe.2010.03.002

Ayuso, J., Perez, D., Saurina, J. (2004). Are capital buffers pro-cyclical? Evidence from Spanish panel data, Journal of Financial Intermediation 13, 249-264.

Bader, M.K.I., Mohamad, S., Mohamed, A., Hassan, T., 2008. Cost, Revenue, and Profit Efficiency of Islamic Versus Conventional Banks: International Evidence Using Data Envelopment Analysis. Islam. Econ. Stud. 15, 54.

Baele, L., Farooq, M., Ongena, S., 2014. Of religion and redemption: Evidence from default on Islamic loans. J. Bank. Financ. 44, 141-159. doi:10.1016/j.jbankfin.2014.03.005

Bashir, A.-H.M., 2003. Determinants of profitability in Islamic banks: Some evidence from the Middle East. Islam. Econ. Stud. 11-1, 32-57.

Basiruddin, R., Ahmed, H., 2017. The role of corporate governance on Shariah non-compliant risk: Evidence from Southeast Asia, in: KFUPM Islamic Banking and Finance Research Conference 2017.

Bauer, P.W., Berger, A.N., Ferrier, G.D., Humphrey, D.B., 1998. Consistency Conditions for Regulatory 
Analysis of Financial Institutions: A Comparison of Frontier Efficiency Methods. J. Econ. Bus. 50, 85-114. doi:https://doi.org/10.1016/S0148-6195(97)00072-6

Beccalli, E., Casu, B., Girardone, C., 2006. Efficiency and Stock Performance in European Banking. J. Bus. Financ. Account. 33, 245-262. doi:10.1111/j.1468-5957.2006.01362.x

Beck, T., Demirgüç-Kunt, A., Merrouche, O., 2013. Islamic vs. conventional banking: Business model, efficiency and stability. J. Bank. Financ. 37, 433-447. doi:https://doi.org/10.1016/j.jbankfin.2012.09.016

Beck, T., Levine, R., Loayza, N., 2000. Finance and the sources of growth. J. financ. econ. 58, 261-300. doi:https://doi.org/10.1016/S0304-405X(00)00072-6

Ben Naceur, S., Goaied, M., 2008. The Determinants of Commercial Bank Interest Margin and Profitability: Evidence from Tunisia. Front. Financ. Econ. 5, 106-130.

Bergbrant, M.C., Campbell, K.T., Hunter, D.M., Owers, J.E., 2016. Does deposit insurance retard the development of non-bank financial markets? J. Bank. Financ. 66, 102-125. doi:https://doi.org/10.1016/j.jbankfin.2016.01.013

Berger, A.N., 1995. The Relationship between Capital and Earnings in Banking. J. Money, Credit Bank. 27, 432-456. doi:10.2307/2077877

Berger, A.N., Bonaccorsi di Patti, E., 2006. Capital structure and firm performance: A new approach to testing agency theory and an application to the banking industry. J. Bank. Financ. 30, 1065-1102. doi:https://doi.org/10.1016/j.jbankfin.2005.05.015

Berger, A.N., Boubakri, N., Guedhami, O., Li, X., 2017. Liquidity creation and financial stability implications of Islamic banking: Evidence from a multinational study, in: KFUPM Islamic Banking and Finance Research Conference 2017.

Berger, A.N., Bouwman, C.H.S., 2009. Bank Liquidity Creation. Rev. Financ. Stud. 22, 3779-3837.

Berger, A.N., Clarke, G.R.G., Cull, R., Klapper, L., Udell, G.F., 2005. Corporate governance and bank performance: A joint analysis of the static, selection, and dynamic effects of domestic, foreign, and state ownership. J. Bank. Financ. 29, 2179-2221. doi:10.1016/j.jbankfin.2005.03.013

Berger, A.N., DeYoung, R., 1997. Problem Loans and Cost Efficiency in Commercial Banks. J. Bank. Financ. 21, 849-870.

Berger, A.N., Hannan, T.H., 1989. The Price-Concentration Relationship in Banking. Rev. Econ. Stat. 71, 291-299. doi:10.2307/1926975

Berger, A.N., Hasan, I., Zhou, M., 2010. The effects of focus versus diversification on bank performance: Evidence from Chinese banks. J. Bank. Financ. 34, 1417-1435. doi:https://doi.org/10.1016/j.jbankfin.2010.01.010

Berger, A.N., Humphrey, D.B., 1997. Efficiency of financial institutions: International survey and directions for future research. Eur. J. Oper. Res. 98, 175-212. doi:https://doi.org/10.1016/S03772217(96)00342-6

Berger, A.N., Mester, L.J., 1997. Inside the black box: What explains differences in the efficiencies of financial institutions? J. Bank. Financ. 21, 895-947. doi:10.1016/S0378-4266(97)00010-1

BIS, 2011. Basel III: A global regulatory framework for more resilient banks and banking systems, Bank for International Settlements.

BIS, 2009. Strengthening the resilience of the banking sector, Basel Committee on Banking Supervision. Bordeleau, É., Graham, C., 2010. The Impact of Liquidity on Bank Profitability, Staff Working Papers. Bank of Canada.

Bitar, M.,Walker T., Pukthuanthong, K., 2018. The effect of bank capital on the risk, efficiency and profitability of banks: Evidence from OECD countries. Journal of International Financial Markets, Institutions and Money 53, pp. 227-262

Bitar, M., Saad,W., Benlemlih, M., (2016).Bank risk and performance in the MENA region: The importance of capital requirements. Economic Systems 40, pp. 398-421

Bourke, P., 1989. Concentration and other determinants of bank profitability in Europe, North America and Australia. J. Bank. Financ. 13, 65-79. doi:https://doi.org/10.1016/0378-4266(89)90020-4 
Boyd, J.H., De Nicoló, G., 2005. The Theory of Bank Risk Taking and Competition Revisited. J. Finance 60, 1329-1343. doi:10.1111/j.1540-6261.2005.00763.x

Boyd, J.H., Runkle, D.E., 1993. Size and performance of banking firms. Testing the predictions of theory. J. Monet. Econ. 31, 47-67. doi:10.1016/0304-3932(93)90016-9

Boyd, J.H., Smith, B.D., 1998. The evolution of debt and equity markets in economic development. Econ. Theory 12, 519-560. doi:10.1007/s001990050234

Breusch, T.S., Pagan, A.R., 1980. The Lagrange Multiplier Test and its Applications to Model Specification in Econometrics. Rev. Econ. Stud. 47, 239-253. doi:10.2307/2297111

Brown, K., Skully, M.T., 2002. International studies in comparative banking: a survey of recent developments. SSRN eLibrary.

Calem, P., Rob, R., 1999. The Impact of Capital-Based Regulation on Bank Risk-Taking. J. Financ. Intermediation 8, 317-352. doi:https://doi.org/10.1006/jfin.1999.0276

Carbó-Valverde, S., Sánchez, L.P., 2013. Financial Stability and Economic Growth BT - Crisis, Risk and Stability in Financial Markets, in: de Guevara Radoselovics, J.F., Monsálvez, J.M.P. (Eds.), . Palgrave Macmillan UK, London, pp. 8-23. doi:10.1057/9781137001832_2

Carvallo, O., Kasman, A., 2005. Cost efficiency in the Latin American and Caribbean banking systems. J. Int. Financ. Mark. Institutions Money 15, 55-72. doi:https://doi.org/10.1016/j.intfin.2004.02.002

Charnes, A., Cooper, W.W., Rhodes, E., 1978. Measuring the efficiency of decision making units. Eur. J. Oper. Res. 2, 429-444. doi:https://doi.org/10.1016/0377-2217(78)90138-8

Choudhury, M.A., Hoque, M.Z., 2006. Corporate governance in Islamic perspective. Corp. Gov. 6, 116128. doi:0.1108/14720700610655132

Cihák, M., Hesse, H., 2007. Cooperative Banks and Financial Stability. IMF Work. Pap. 7, 36. doi:10.5089/9781451865660.001

Čihák, M., Hesse, H., 2010. Islamic Banks and Financial Stability: An Empirical Analysis. J. Financ. Serv. Res. 38, 95-113. doi:10.1007/s10693-010-0089-0

Coelli, T., Perelman, S., 2000. Technical efficiency of European railways: a distance function approach. Appl. Econ. 32, 1967-1976.

Cornett, M.M., Guo, L., Khaksari, S., Tehranian, H., 2010. The impact of state ownership on performance differences in privately-owned versus state-owned banks: An international comparison. J. Financ. Intermediation 19, 74-94. doi:https://doi.org/10.1016/j.jfi.2008.09.005

Cummins, J.D., Weiss, M.A., 2000. Analyzing Firm Performance in the Insurance Industry Using Frontier Efficiency and Productivity Methods BT - Handbook of Insurance, in: Dionne, G. (Ed.), . Springer Netherlands, Dordrecht, pp. 767-829. doi:10.1007/978-94-010-0642-2_24

D’Mello, R., Miranda, M., 2010. Long-term debt and overinvestment agency problem. J. Bank. Financ. 34, 324-335. doi:https://doi.org/10.1016/j.jbankfin.2009.07.021

Dahl, D., Shrieves, R.E., 1990. The impact of regulation on bank equity infusions. J. Bank. Financ. 14, 1209-1228. doi:https://doi.org/10.1016/0378-4266(90)90010-Y

DeAngelo, H., Stulz, R.M., 2015. Liquid-claim production, risk management, and bank capital structure: Why high leverage is optimal for banks. J. financ. econ. 116, 219-236. doi:10.1016/j.jfineco.2014.11.011

Deelchand, T., Padgett, C., 2009. The relationship between risk, capital and efficiency: Evidence from Japanese cooperative banks. SSRN eLibrary. doi:dx.doi.org/10.2139/ssrn.1525423

Demirguc-Kunt, A., Huizinga, H., 1999. Determinants of Commercial Bank Interest Margins and Profitability: Some International Evidence. World Bank Econ. Rev. 13, 379-408.

Demirgüç-Kunt, A., Huizinga, H., 2010. Bank activity and funding strategies: The impact on risk and returns. J. financ. econ. 98, 626-650. doi:https://doi.org/10.1016/j.jfineco.2010.06.004

Demirgüç-Kunt, A., Maksimovic, V., 1998. Law, Finance, and Firm Growth. J. Finance 53, 2107-2137. doi:10.1111/0022-1082.00084

Demsetz, R., Saidenberg, M.R., Strahan, P.E., 1996. Banks with something to lose: the disciplinary role of franchise value. Econ. Policy Rev. 1-14.

DeYoung, R., 1998. Management Quality and X-Inefficiency in National Banks. J. Financ. Serv. Res. 13, 
5-22. doi:10.1023/A:1007965210067

Di, L., Shaiban, M.S., Shavkatovich Hasanov, A., 2017. Contagion effect from US banking to conventional and Islamic banking in dual-banking system during financial crisis, in: KFUPM Islamic Banking and Finance Research Conference 2017.

Dong, Y., Girardone, C., Kuo, J.-M., 2017. Governance, efficiency and risk taking in Chinese banking. Br. Account. Rev. 49, 211-229. doi:https://doi.org/10.1016/j.bar.2016.08.001

Ebrahim, M.-S., 1999. Integrating Islamic and conventional project finance. Thunderbird Int. Bus. Rev. 41, 583-609. doi:10.1002/tie.4270410416

Ediz, T., Michael, I., Perraudin, W., 1998. The impact of capital requirements on U.K. bank behaviour. Econ. Policy Rev. 15-22.

El-Gamal, M.A., Inanoglu, H., 2005. Inefficiency and heterogeneity in Turkish banking: 1990-2000. J. Appl. Econom. 20, 641-664. doi:10.1002/jae.835

Elnahass, M., Izzeldin, M., Abdelsalam, O., 2014. Loan loss provisions, bank valuations and discretion: A comparative study between conventional and Islamic banks. J. Econ. Behav. Organ. 103, S160 S173. doi:10.1016/j.jebo.2013.08.018

EY, 2017. Banking in emerging markets: GCC FinTech play.

Farag, H., Mallin, C., Ow-Yong, K., 2017. Corporate governance in Islamic banks: New insights for dual board structure and agency relationships. J. Int. Financ. Mark. Institutions Money. doi:https://doi.org/10.1016/j.intfin.2017.08.002

Fethi, M.D., Pasiouras, F., 2010. Assessing bank efficiency and performance with operational research and artificial intelligence techniques: A survey. Eur. J. Oper. Res. 204, 189-198.

Fiordelisi, F., Marques-ibanez, D., Molyneux, P., 2011. Efficiency and risk in European banking. J. Bank. Financ. 35, 1315-1326. doi:10.1016/j.jbankfin.2010.10.005

Fiordelisi, F., Molyneux, P., 2010. The determinants of shareholder value in European banking. J. Bank. Financ. 34, 1189-1200. doi:https://doi.org/10.1016/j.jbankfin.2009.11.018

Fried, H.O., Lovell, C.A.K., Schmidt, S.S., 2008. The measurement of productive efficiency and productivity growth. Oxford University Press.

Fries, S., Taci, A., 2005. Cost efficiency of banks in transition: Evidence from 289 banks in 15 postcommunist countries. J. Bank. Financ. 29, 55-81. doi:10.1016/j.jbankfin.2004.06.016

Goddart, J.A., Molyneux, P., Wilson, J.O.S., 2007. European Banking: Efficiency, Technology and Growth. Wiley.

Gopalan, R., Gormley, T.A., 2013. Do Public Equity Markets Matter in Emerging Economies? Evidence from India. Rev. Financ. 17, 1571-1615.

Gorton, G., Huang, L., 2004. Liquidity, Efficiency, and Bank Bailouts. Am. Econ. Rev. 94, 455-483.

Gorton, G., Rosen, R., 1995. Corporate Control, Portfolio Choice, and the Decline of Banking. J. Finance 50, 1377-1420. doi:10.1111/j.1540-6261.1995.tb05183.x

Grigorian, D.A., Manole, V., 2006. Determinants of commercial bank performance in transition: an application of data envelopment analysis. Comp. Econ. Stud. 48, 497-522.

Gropp, R., Heider, F., 2010. The Determinants of Bank Capital Structure. Rev. Financ. 14, 587-622.

Grossman, S., Hart, O., 1982. Corporate Financial Structure and Managerial Incentives. National Bureau of Economic Research, Inc, p. 107-140 BT-The Economics of Information and Unc.

Haq, M., Heaney, R., 2012. Factors determining European bank risk. J. Int. Financ. Mark. Institutions Money 22, 696-718. doi:https://doi.org/10.1016/j.intfin.2012.04.003

Harvey, C.R., Lins, K. V, Roper, A.H., 2004. The effect of capital structure when expected agency costs are extreme. J. financ. econ. 74, 3-30. doi:https://doi.org/10.1016/j.jfineco.2003.07.003

Hasan, M., Dridi, J., 2011. The effects of the global crisis on Islamic and conventional banks: A comparative study. J. Int. Commer. Econ. Policy 2, 163-200.

Hassan, T., Mohamad, S., Khaled I. Bader, M., 2009. Efficiency of conventional versus Islamic banks: evidence from the Middle East. Int. J. Islam. middle East. Financ. Manag. 2, 46-65.

Hayat, R., Den Butter, F., Kock, U., 2013. Halal Certification for Financial Products: A Transaction Cost Perspective. J. Bus. Ethics 117, 601-613. doi:10.1007/s10551-012-1534-9 
Hesse, H., Jobst, A.A., Sole, J., 2008. Trends and challenges in Islamic finance. World Econ. 9, 175-193. Hoggarth, G., Milne, A., Wood, G.E., 2001. Alternative Routes to Banking Stability: A Comparison of UK and German Banking Systems BT - Financial Competition, Risk and Accountability: British and German Experiences, in: Frowen, S.F., McHugh, F.P. (Eds.), . Palgrave Macmillan UK, London, pp. 11-32. doi:10.1007/978-1-349-65236-5_2

Hu, J.-L., Yu, H.-E., 2015. Risk, Capital, and Operating Efficiency: Evidence from Taiwan's Life Insurance Market. Emerg. Mark. Financ. Trade 51, S121-S132. doi:10.1080/1540496X.2014.998907

Hughes, J., Mester, L., 1998. Bank Capitalization and Cost: Evidence of Scale Economies in Risk Management and Signaling. Rev. Econ. Stat. 80, 314-325.

Hughes, J.P., Mester, L.J., Moon, C.-G., 2001. Are scale economies in banking elusive or illusive?: Evidence obtained by incorporating capital structure and risk-taking into models of bank production. J. Bank. Financ. 25, 2169-2208. doi:https://doi.org/10.1016/S0378-4266(01)00190-X Hughes, J.P. and Moon, C., (1997), "Measuring bank efficiency when managers trade return for reduced risk", Department of Economics Rutgers University Working Paper, No. 1995-20.

Iannotta, G., Nocera, G., Sironi, A., 2007. Ownership structure, risk and performance in the European banking industry. J. Bank. Financ. 31, 2127-2149.

doi:https://doi.org/10.1016/j.jbankfin.2006.07.013

IFSB, 2011. Guidance note in connection with the IFSB Capital Adequacy Standard: The determination of Alfa in the capital adequacy ratio for institutions (other than insurance institutions) offering only financial Islamic services. Malaysia.

Iqbal, M., Llewellyn, D.T., 2002. Islamic banking and finance: new perspectives on profit sharing and risk. Edward Elgar Publishing.

Jacques, K., Nigro, P., 1997. Risk-based capital, portfolio risk, and bank capital: A simultaneous equations approach. J. Econ. Bus. 49, 533-547. doi:https://doi.org/10.1016/S0148-6195(97)00038-6

Jeitschko, T.D., Jeung, S.D., 2005. Incentives for risk-taking in banking - A unified approach. J. Bank. Financ. 29, 759-777. doi:https://doi.org/10.1016/j.jbankfin.2004.05.028

Jensen, M.C., 1986. Agency Costs of Free Cash Flow, Corporate Finance, and Takeovers. Am. Econ. Rev. 76, 323-329.

Jensen, M.C., Meckling, W.H., 1976. Theory of the firm: Managerial behavior, agency costs and ownership structure. J. financ. econ. 3, 305-360. doi:https://doi.org/10.1016/0304-405X(76)90026$\mathrm{X}$

Jiang, C., Feng, G., Zhang, J., 2012. Corporate governance and bank performance in China. J. Chinese Econ. Bus. Stud. 10, 131-146. doi:10.1080/14765284.2012.673779

Johnes, J., Izzeldin, M., Pappas, V., 2014. A comparison of performance of Islamic and conventional banks 2004-2009. J. Econ. Behav. Organ. 103, 1-15. doi:10.1016/j.jebo.2013.07.016

Johnes, J., Ongena, S., Pappas, V., Tsionas, E.G., Izzeldin, M., 2017. Another Great Convergence? Are Islamic and convenitonal banks converging in efficiency across all countries? SSRN eLibrary. doi:dx.doi.org/10.2139/ssrn.2960018

Kabir Hassan, M., Aliyu, S., 2017. A Contemporary Survey of Islamic Banking Literature. J. Financ. Stab. doi:https://doi.org/10.1016/j.jfs.2017.11.006

Kahane, Y., 1977. Capital adequacy and the regulation of financial intermediaries. J. Bank. Financ. 1, 207-218. doi:https://doi.org/10.1016/0378-4266(77)90007-3

Kamarudin, F., Nordin, B.A.A., Muhammad, J., Hamid, M.A.A., 2014. Cost, Revenue and Profit Efficiency of Islamic and Conventional Banking Sector: Empirical Evidence from Gulf Cooperative Council Countries. Glob. Bus. Rev. 15, 1-24. doi:10.1177/0972150913515579

Karas, A., Schoors, K., Weill, L., 2010. Are private banks more efficient than public banks? Econ. Transit. 18, 209-244. doi:10.1111/j.1468-0351.2009.00364.x

Karasulu, M., 2001. The Profitability of the Banking Sector in Korea. 
Kwan, S., Eisenbeis, R.A., 1997. Bank Risk, Capitalization, and Operating Efficiency. J. Financ. Serv. Res. 12, 117-131. doi:10.1023/A:1007970618648

Laeven, L., Levine, R., 2009. Bank governance, regulation and risk taking. J. financ. econ. 93, 259-275. doi:10.1016/j.jfineco.2008.09.003

Lepetit, L., Nys, E., Rous, P., Tarazi, A., 2008. The expansion of services in European banking: Implications for loan pricing and interest margins. J. Bank. Financ. 32, 2325-2335. doi:https://doi.org/10.1016/j.jbankfin.2007.09.025

Levine, R., Zervos, S., 1998. Stock Markets, Banks, and Economic Growth. Am. Econ. Rev. 88, 537558.

Mamatzakis, E., 2015. Risk and efficiency in the Central and Eastern European banking industry under quantile analysis. Quant. Financ. 15, 553-567. doi:10.1080/14697688.2012.715245

Marcus, A.J., 1983. The Bank Capital Decision: A Time Series--Cross Section Analysis. J. Finance 38, 1217-1232. doi:10.2307/2328021

Mare, D.S., Moreira, F., Rossi, R., 2017. Nonstationary Z-Score measures. Eur. J. Oper. Res. 260, 348358. doi:10.1016/j.ejor.2016.12.001

Maudos, J., Pastor, J.M., Perez, F., Quesada, J., 2002. Cost and profit efficiency in European banks. J. Int. Financ. Mark. Institutions Money 12, 33-58.

Meslier, C., Risfandy, T., Tarazi, A., 2017. Dual market competition and deposit rate setting in Islamic and conventional banks. Econ. Model. 63, 318-333. doi:https://doi.org/10.1016/j.econmod.2017.02.013

Miller, S.M., Noulas, A.G., 1996. The technical efficiency of large bank production. J. Bank. Financ. 20, 495-509. doi:https://doi.org/10.1016/0378-4266(95)00017-8

Mobarek, A., Kalonov, A., 2014. Comparative performance analysis between conventional and Islamic banks: empirical evidence from OIC countries. Appl. Econ. 46, 253-270.

Mokhtar, H.S.A., Abdullah, N., Alhabshi, S.M., 2008. Efficiency and competition of Islamic banking in Malaysia. Humanomics 24, 28-48. doi:10.1108/08288660810851450

Mollah, S., Hassan, M.K., Al Farooque, O., Mobarek, A., 2017. The governance, risk-taking, and performance of Islamic banks. J. Financ. Serv. Res. 51, 195-219.

Mollah, S., Zaman, M., 2015. Shari'ah supervision, corporate governance and performance: Conventional vs. Islamic banks. J. Bank. Financ. 58, 418-435. doi:https://doi.org/10.1016/j.jbankfin.2015.04.030

Moon, H.R., Perron, B., 2005. Efficient Estimation of the Seemingly Unrelated Regression Cointegration Model and Testing for Purchasing Power Parity. Econom. Rev. 23, 293-323. doi:10.1081/ETC200040777

Olson, D., Zoubi, T., 2017. Convergence in bank performance for commercial and Islamic banks during and after the Global Financial Crisis. Q. Rev. Econ. Financ. 65, 71-87. doi:https://doi.org/10.1016/j.qref.2016.06.013

Olson, D., Zoubi, T.A., 2008. Using accounting ratios to distinguish between Islamic and conventional banks in the GCC region. Int. J. Account. 43, 45-65. doi:10.1016/j.intacc.2008.01.003

Pappas, V., Ongena, S., Izzeldin, M., Fuertes, A.M., 2017. A Survival Analysis of Islamic and Conventional Banks. J. Financ. Serv. Res. 51, 1-36. doi:10.1007/s10693-016-0239-0

Pellegrina, L.D., 2012. Does capitalization enhance efficient risk undertaking?: A comparison between Islamic and conventional banks. Account. Res. J. 25, 185-207. doi:10.1108/10309611211290167

Peltzman, S., 1970. Capital Investment in Commercial Banking and Its Relationship to Portfolio Regulation. J. Polit. Econ. 78, 1-26.

Peristiani, S., 1997. Do Mergers Improve the X-Efficiency and Scale Efficiency of U.S. Banks? Evidence from the 1980s. J. Money, Credit Bank. 29, 326-337.

Perry, P., 1992. Do banks gain or lose from inflation? J. Retail Bank. 14, 25-31.

Peura, S., Keppo, J., 2006. Optimal Bank Capital with Costly Recapitalization. J. Bus. 79, 2163-2201. doi: $10.1086 / 503660$

Podpiera, J., Weill, L., 2008. Bad luck or bad management? Emerging banking market experience. J. Financ. Stab. 4, 135-148. doi:https://doi.org/10.1016/j.jfs.2008.01.005 
Rehman, S.S., Askari, H., 2010. How Islamic are Islamic Countries? Glob. Econ. J. 10.

Rice, T., Strahan, P.E., 2010. Does Credit Competition Affect Small-Firm Finance? J. Finance 65, 861889. doi:10.1111/j.1540-6261.2010.01555.x

Rime, B., 2001. Capital requirements and bank behaviour: Empirical evidence for Switzerland. J. Bank. Financ. 25, 789-805. doi:https://doi.org/10.1016/S0378-4266(00)00105-9

Saeed, M., Izzeldin, M., 2016. Examining the relationship between default risk and efficiency in Islamic and conventional banks. J. Econ. Behav. Organ. 132, 127-154. doi:10.1016/j.jebo.2014.02.014

S\&P Global Ratings, ,2017. Islamic FInance Outlook , 2018 Edition.

Salas, V., Saurina, J., 2003. Deregulation, market power and risk behaviour in Spanish banks. Eur. Econ. Rev. 47, 1061-1075. doi:https://doi.org/10.1016/S0014-2921(02)00230-1

Schaeck, K., Cihák, M., 2014. Competition, Efficiency, and Stability in Banking. Financ. Manag. 43, 215-241. doi:10.1111/fima.12010

Scholtens, B., 2000. Financial regulation and financial system architecture in Central Europe. J. Bank. Financ. 24, 525-553. doi:https://doi.org/10.1016/S0378-4266(99)00079-5

Schure, P., Wagenvoort, R., 1999. Economies of scale and efficiency in European banking: new evidence. European Investment Bank, Luxembourg.

Sealey, C.W., Lindley, J.T., 1977. Inputs, Outputs and a Theory of Production and Cost at Depository Financial Institutions. J. Finance 32, 1251-1266. doi:10.1111/j.1540-6261.1977.tb03324.x

Semih Yildirim, H., Philippatos, G.C., 2007. Efficiency of Banks: Recent Evidence from the Transition Economies of Europe, 1993-2000. Eur. J. Financ. 13, 123-143. doi:10.1080/13518470600763687

Shrieves, R.E., Dahl, D., 1992. The relationship between risk and capital in commercial banks. J. Bank. Financ. 16, 439-457. doi:https://doi.org/10.1016/0378-4266(92)90024-T

Smirlock, M., 1985. Evidence on the (Non) Relationship between Concentration and Profitability in Banking. J. Money, Credit Bank. 17, 69-83. doi:10.2307/1992507

Sorwar, G., Pappas, V., Pereira, J., Nurullah, M., 2016. To debt or not to debt: Are Islamic banks less risky than conventional banks? J. Econ. Behav. Organ. 132, 113-126. doi:https://doi.org/10.1016/j.jebo.2016.10.012

Srairi, S.A., 2010. Cost and profit efficiency of conventional and Islamic banks in GCC countries. J. Product. Anal. 34, 45-62. doi:10.1007/s11123-009-0161-7

Staikouras, C.K., Wood, G.E., 2004. The determinants of European bank profitability. Int. Bus. Econ. Res. J. 3, 57-68.

Stiglitz, J.E., 2000. Capital Market Liberalization, Economic Growth, and Instability. World Dev. 28, 1075-1086. doi:https://doi.org/10.1016/S0305-750X(00)00006-1

Stulz, R., 1990. Managerial discretion and optimal financing policies. J. financ. econ. 26, 3-27. doi:https://doi.org/10.1016/0304-405X(90)90011-N

Sufian, F., Noor, M.A.N.M., 2009. The determinants of Islamic banks' efficiency changes: Empirical evidence from the MENA and Asian banking sectors. Int. J. Islam. Middle East. Financ. Manag. 2, 120-138. doi:10.1108/17538390910965149

Sundararajan, V., Errico, L., 2002. Islamic financial institutions and products in the global financial system: Key issues in risk management and challenges ahead. International Monetary Fund.

Tan, Y., Floros, C., 2013. Risk, capital and efficiency in Chinese banking. J. Int. Financ. Mark. Institutions Money 26, 378-393. doi:https://doi.org/10.1016/j.intfin.2013.07.009

Tarashev, N., Borio, C., Tsatsaronis, K., 2009. The systemic importance of financial institutions. BIS Q. Rev. 75-87.

Uddin, H.M., Humayun Kabir, S., Mollah, S., 2017. Corporate earnings uncertainty in Islamic banking system: An analysis and evidence, in: KFUPM Islamic Banking and Finance Research Conference 2017.

Vallascas, F., Mollah, S., Keasey, K., 2017. Does the impact of board independence on large bank risks change after the global financial crisis? J. Corp. Financ. 44, 149-166. doi:10.1016/j.jcorpfin.2017.03.011

Wall, L.D., 1989. A plan for reducing future deposit insurance losses: Puttable subordinated debt. Econ. 
Rev. 74, 2-17.

Wall, L.D., Peterson, D.R., 1988. Capital changes at large affiliated banks. J. Financ. Serv. Res. 1, 253275. doi:10.1007/BF00114853

Weill, L., 2003. Banking efficiency in transition economies. Econ. Transit. 11, 569-592. doi:10.1111/1468-0351.00155

Wheelock, D.C., Wilson, P.W., 1995. Explaining Bank Failures: Deposit Insurance, Regulation, and Efficiency. Rev. Econ. Stat. 77, 689-700. doi:10.2307/2109816

Williams, J., 2004. Determining management behaviour in European banking. J. Bank. Financ. 28, 24272460. doi:https://doi.org/10.1016/j.jbankfin.2003.09.010

Zellner, A., 1962. An Efficient Method of Estimating Seemingly Unrelated Regressions and Tests for Aggregation Bias. J. Am. Stat. Assoc. 57, 348-368. doi:10.2307/2281644

Zuhroh, I., Ismail, M., Maskie, G., 2015. Cost Efficiency of Islamic Banks in Indonesia - A Stochastic Frontier Analysis. Procedia - Soc. Behav. Sci. 211, 1122-1131. doi:10.1016/j.sbspro.2015.11.150 